\title{
FINANCIAL HARDSHIP BEFORE AND AFTER SOCIAL SECURITY'S EARLY ELIGIBILITY AGE
}

\author{
Richard W. Johnson and Gordon B.T. Mermin* \\ CRR WP 2009-8 \\ Released: March 2009 \\ Draft Submitted: January 2009
}
Center for Retirement Research at Boston College
Hovey House
140 Commonwealth Avenue
Chestnut Hill, MA 02467

Tel: 617-552-1762 Fax: 617-552-0191
* Richard W. Johnson is a senior fellow at The Urban Institute. Gordon B.T. Mermin is a research associate at The Urban Institute. The research reported herein was supported by the Center for Retirement Research at Boston College pursuant to a grant from the U.S. Social Security Administration funded as part of the Retirement Research Consortium. The findings and conclusions are solely those of the authors and should not be construed as representing the opinions or policy of the Social Security Administration or any agency of the Federal Government; the Center for Retirement Research at Boston College; or the Urban Institute, its trustees, or its sponsors. The authors are grateful to Corina Mommaerts and Desmond Toohey for outstanding research assistance.
(C) 2009, by Richard W. Johnson and Gordon B.T. Mermin. All rights reserved. Short sections of text, not to exceed two paragraphs, may be quoted without explicit permission provided that full credit, including (C) notice, is given to the source.




\title{
About the Center for Retirement Research
}

The Center for Retirement Research at Boston College, part of a consortium that includes parallel centers at the University of Michigan and the National Bureau of Economic Research, was established in 1998 through a grant from the Social Security Administration. The Center's mission is to produce first-class research and forge a strong link between the academic community and decision makers in the public and private sectors around an issue of critical importance to the nation's future. To achieve this mission, the Center sponsors a wide variety of research projects, transmits new findings to a broad audience, trains new scholars, and broadens access to valuable data sources.

\author{
Center for Retirement Research at Boston College \\ Hovey House \\ 140 Commonwealth Avenue \\ Chestnut Hill, MA 02467 \\ phone: 617-552-1762 fax: 617-552-0191 \\ e-mail: crr@bc.edu \\ www.bc.edu/crr
}

Affiliated Institutions:

The Brookings Institution

Massachusetts Institute of Technology

Syracuse University

Urban Institute 


\begin{abstract}
Although poverty rates for Americans ages 65 and older have plunged over the past half century, many people continue to fall into poverty in their late fifties and early sixties. This study examines financial hardship rates in the years before qualifying for Social Security retirement benefits at age 62 and investigates how the availability of Social Security improves economic well-being at later ages. The analysis follows a sample of adults from the 1937-39 birth cohort for 14 years, tracking their employment, disability status, and income as they age from their early 50s until their late 60s. It measures the share of older adults who appear to have been forced into retirement by health or employment shocks and the apparent impact of involuntary retirement on low-income rates. The study also estimates models of the likelihood that older adults experience financial hardship before reaching Social Security’s early eligibility age.

The results show that the likelihood of experiencing financial hardship increases significantly as people approach Social Security’s early eligibility age. The increase in hardship rates is concentrated among workers with limited education and health problems. For example, among those who did not complete high school, hardship rates increase from 23 percent at ages 52 to 54 to 31 percent at ages 60 to 61, a relative increase of 36 percent. Hardship rates decline after age 62, when most people qualify for Social Security retirement benefits. These findings highlight the fragility of the income support system for Americans in their fifties and early sixties.
\end{abstract}




\section{Introduction}

Although poverty rates for Americans ages 65 and older have plunged over the past half century, many people in their late fifties and early sixties continue to run the risk of falling into poverty. Disability and job displacement frequently create financial hardship for people throughout the working-age population-often forcing workers out of the labor force or into unemployment—but the risks are particularly serious in the years just before age 62. Health problems become increasingly common with age, and older people displaced from their jobs by layoffs or business closings often face special difficulty finding work. The limited availability of public income supports magnifies economic insecurities for older workers who are not yet 62, when entitlement to Social Security retirement benefits begins. Social Security disability insurance (SSDI) benefits are available only to workers who successfully navigate an arduous and unpredictable application process, and may begin no sooner than five months after disability onset. SSDI beneficiaries must also satisfy the program’s work history requirement, which disqualifies some people. Increasing numbers of displaced workers fail to qualify for unemployment benefits, and those who do qualify receive benefits for only a limited time.

Social Security’s financial problems increase the need for up-to-date information on the economic hardships experienced by Americans in their fifties and early sixties. Numerous analysts have advocated raising Social Security’s entitlement ages to reduce or eliminate the system’s long-term deficit, primarily because average lifespans and time spent in retirement have increased and old-age disability has declined. This approach, however, could substantially reduce economic well-being for older people who are struggling under the current system. A better understanding of the prevalence, intensity, and drivers of economic hardship in the years 
immediately before age 62 is essential to assessing the wisdom of increasing Social Security's retirement ages.

This study examines the extent to which workers experience increased hardship in the years before qualifying for Social Security retirement benefits at age 62 and how much the availability of Social Security improves economic well-being at later ages. Using recent data from a nationally representative survey, the paper computes rates of financial hardship in 2005 from ages 53 to 68, assesses how rates vary by demographic characteristics, and examines trends since 1991. The study then follows a cohort of older adults for 14 years, tracking their employment, disability status, and income as they age from their early 50s in 1991 until their late 60s in 2005. We measure the share of older adults who appear to have been forced into retirement by health or employment shocks and the apparent impact of involuntary retirement on low-income rates. A final set of analyses estimate models of the likelihood that older adults experience financial hardship before reaching the Social Security early entitlement age.

The results show that financial hardship increases substantially for people with limited education and health problems as they approach Social Security's early eligibility age. Hardship rates are particularly high for less-skilled workers who retire early. However, their economic status improves significantly when they reach age 62 and qualify for Social Security retirement benefits, highlighting the important role that Social Security plays in bolstering the economic security of low-income older adults. 


\section{Background}

Many workers begin exiting the labor force before they qualify for Social Security benefits at age 62. In 2008, nearly one-third (32 percent) of men ages 60 to 61 did not participate in the labor force, compared with less than one-tenth (8 percent) of men ages 40 to 44 (Bureau of Labor Statistics 2008). About 14 percent of men and 24 percent of women ages 50 to 61 did not participate in the labor force in any month in 2001 (Congressional Budget Office [CBO] 2004), and fewer than 40 percent of workers born between 1931 and 1941 were still at their career jobs by age 60 (Cahill, Giandrea, and Quinn 2005).

Although many workers with ample resources choose to retire early, poor health or job layoffs force others to leave the labor force before they qualify for retirement benefits. About one in four workers ages 51 to 55 develop serious health problems by age 62 that limit their ability to work, and one in five are laid off from their jobs (Johnson, Mermin, and Murphy 2007). Own health problems can lead to early retirement (Bound et al. 1998; McGarry 2004), and workers sometimes have to cutback on their work hours to care for ill family members (Coile 2003; Johnson and Favreault 2001; Johnson and LoSasso 2006). Onset of health problems may be particularly problematic for workers with physically demanding jobs. About 7 percent of all workers and 17 percent of workers without high school diplomas hold highly physically demanding jobs that require strength, bending or twisting, or quick reaction time (Johnson, Mermin, and Resseger 2007). Older workers displaced from their jobs often encounter problems finding work (Chan and Stevens 2001; Munnell et al. 2006), and those who become reemployed tend to earn much less on their new jobs than they did on their former jobs (Couch, Jolly, and Placzek 2009), perhaps because employers are reluctant to hire workers near the end of their careers or because older people face outright discrimination in the labor market (Lahey 2008). 
Some workers pushed out of the labor force may avoid hardship by falling back on assets and other income sources. Workers who develop serious health problems may qualify for disability benefits, and unemployment benefits may bridge the gap to Social Security for workers who are laid off. Employer-provided pensions and income from spouses may also cushion the blow. But many lack these resources and may struggle financially until they reach the Social Security eligibility age. For example, nearly half of all workers lack pension coverage (Bureau of Labor Statistics 2007), and only about a quarter of adults developing serious health problems in their fifties qualify for disability benefits (Johnson, Mermin, and Murphy 2007). Although the vast majority of jobs in the U.S. are covered by unemployment insurance, only 36 percent of the unemployed in 2007 received benefits (Simms and Kuehn 2008). Many workers are ineligible for benefits because they did not earn enough or work long enough before losing their jobs. Additionally, those awarded unemployment benefits receive only temporary assistance; benefits usually run out after 26 weeks. Risk of pre-retirement hardship may be greatest for workers with limited education, who are more likely both to develop health problems and to work in physically demanding occupations and less likely to have other resources to fall back on if pushed out of the labor force.

Although hardship among retirees and families with children has been thoroughly researched (Betson and Michael 1997; Butrica, Murphy, and Zedlewski 2008; Englehardt and Gruber 2004; Holzer et al. 2007; Hurd 1990; Johnson and Smeeding 2000; Sawhill 1988; Smolensky, Danziger, and Gottschalk 1988), less is known about hardship in the years leading up to Social Security eligibility. Previous studies have shown that poverty rates among adults in their fifties are much higher for those out of the labor force—particularly disabled adults—-than for workers. Among adults ages 50 to 61, about 21 percent of those out of the labor force in 
every month of 2001 were impoverished, compared with just 3 percent of adults participating in the labor force (CBO 2004).

Researchers have attempted to assess how many adults would face substantial hardship if early Social Security benefits were not available by comparing the characteristics of workers who take up Social Security before the normal retirement age with those who delay take-up (Burkhauser, Couch, and Phillips 1996; CBO 1999; Leonesio, Vaughan, and Wixon 2000; Panis et al. 2002). Many workers taking up Social Security early appear wealthy enough to have voluntarily retired early, rather than having been forced out early. Early takers have wealth levels similar to workers who delay take-up and have higher pension coverage rates. More than threequarters of workers taking up Social Security early are healthy. Yet, some early takers appear as if they would suffer significant hardship if early benefits were not available. Compared with workers who delay take-up, early takers are more likely to have health-related work limitations, lack a high school diploma, and work in blue-collar occupations. These studies conclude that about 10 percent of early takers have health-related work limitations and lack pension income and would therefore suffer financially if early Social Security benefits were eliminated. Our study further examines the extent to which early Social Security benefits reduce hardship by examining hardship rates before and after age 62.

\section{Methods}

To measure financial hardship in the years preceding and following Social Security eligibility, we examine data from the Health and Retirement Study (HRS), a large, nationally representative survey of older Americans. Fielded by the University of Michigan’s Survey Research Center with primary funding from the National Institute on Aging, the HRS began 
interviewing 12,652 respondents ages 51 to 61 and their spouses (of any age) in 1992. These respondents have been reinterviewed every other year through 2006. ${ }^{1}$ HRS began interviewing a cohort of respondents ages 70 and older in 1993, and a cohort ages 68 to 74 in 1998.

Additionally, every six years beginning in 1998 they introduce a new cohort of respondents ages 51 to 56. Each of these cohorts are reinterviewed with the original HRS cohort. In 2006, then, the survey collected data on a nationally representative sample of Americans ages 53 and older, and their spouses. HRS oversamples African Americans, Hispanics, and Florida residents, but includes sampling weights that can be used to generate estimates that reflect the underlying population. Detailed data are collected on a wide range of topics, including income, assets, employment, employment history, health and disability, and demographics. ${ }^{2}$

\section{Measures}

One of HRS' important strengths is the high quality of its income measures (Hurd, Juster, and Smith 2003). At each interview the HRS asks respondents (or financially knowledgeable spouses when both spouses in a couple are interviewed) about how much they and their spouses received during the previous calendar year from earnings, pension and annuity benefits, Social Security retirement benefits, Social Security disability benefits and Supplemental Security Income (SSI), income from assets, unemployment insurance and Workers Compensation benefits, other government transfers, and other sources. Respondents who are unable to provide an exact amount are asked whether the payments fall within certain ranges, and RAND has imputed missing responses consistently across interview waves. However, the survey does not

\footnotetext{
${ }^{1}$ The 2008 survey has been fielded, and additional biennial surveys are planned.

${ }^{2}$ The Rand Center for the Study on Aging has processed some HRS data and offers these cleaned files to the public. Our analysis uses these files (version $\mathrm{H}$ ) whenever possible.
} 
collect reliable information on income received by household members who are not the respondent's spouse or partner, so our estimates of household income may be understated. We express all income measures in constant 2005 dollars, as adjusted by the change in the consumer price index (CPI).

Our financial hardship estimates are based on the official U.S. Census Bureau poverty thresholds, designed to indicate the bare minimum amount of income necessary to get by. They were originally computed as the cost of a minimally adequate diet in 1963, multiplied by three to capture nonfood living expenses (Orshansky 1963). They increase with household size, are somewhat lower for households headed by an adult age 65 or older than for those headed by younger adults, and adjust each year by the change in the CPI. Doubts about how well the official poverty thresholds describe today's spending needs have been growing, particularly since the underlying data used to compute the original thresholds are now so old (Blank and Greenberg 2008; Citro and Michael 1995). In fact, the official poverty measure appears to understate the number of adults ages 65 and older with inadequate income (Butrica, Murphy, and Zedlewski 2008). However, our purpose in this paper is not to assess the appropriateness of the poverty measure, but instead to use the official threshold as a rough indicator of financial hardship and to assess how hardship rates vary as people approach and surpass traditional retirement ages.

We identify respondents who experience financial hardship in two ways. Our first measure includes only those whose combined own income and spousal income (or only own income if they are not married or partnered) falls below 100 percent of the official federal poverty level. Because the poverty threshold is so low, we alternatively define financial hardship to include those with combined own income and spousal income (or just own income if appropriate) that falls below 125 percent of the poverty level. We use the thresholds for adults 
younger than 65 throughout (even for those older than 65), because one of our goals is to assess how income adequacy varies as people age, and we do not want observed trends to be confounded by abrupt changes in poverty thresholds. We use the threshold that corresponds to the respondent's family size, based on information reported in the HRS.

We construct measures of health status, job displacement, and employment transitions that likely help account for changes in economic hardship rates. We identify adults as having work-limiting health problems if they report a health problem that limits the type or amount of work that they can do. Another measure indicates whether respondents have ever been laid off from their jobs or lost their jobs because of a business closing between the baseline interview and age 62, based on responses to survey questions about why they left their previous jobs. We also create five mutually exclusive employment transition categories for adults ages 53 to 55 in 1992: (1) those who are employed full time (working 35 or more hours per week) at every interview wave until age 62; (2) those employed full-time in 1992 who transition directly to zero hours of work before age 62 and never return to work (either part-time or full-time) before age 62; (3) those employed full-time in 1992 who transition to part-time work before age 62 and never return to full-time work again (although some move in and out of part-time employment); (4) those who work intermittently between ages 53 to 55 and age 62; (5) and those who never work between ages 53 to 55 and age 62 . The intermittent work category includes workers who do not work full-time at baseline and those who move in and out of full-time work. These work transition categories are based on work status at the time of the survey interviews, and thus do not reflect work status between the waves. As a result, some people who we describe as having never worked may in fact have been employed at some point between 1992 and age 62, but they were not employed at the survey interviews. 


\section{Tabulations}

The analysis begins by computing financial hardship rates at points in time. We first compute hardship rates in 2005 for three- and four-year age groups, separately by gender, education, race, marital status, and health status, for a sample of adults ages 52 to 68 . We also examine how hardship rates vary in 1991, 1997, and 2003 for adults ages 50 to 55 and those ages 56 to 60.

The analysis then computes hardship rates for a sample of 2,830 respondents born between 1937 and 1939 as they age from 52 to 54 in 1991 to ages 66 to 68 in 2005 . In 1999, the sample ranges from ages 60 to 62, and in 2001 it ranges from 62 to 64. Because one of our goals is to measure how the availability of Social Security retirement benefits at age 62 affects economic well-being, grouping some 62-year-old Social Security recipients with adults a few years younger may understate financial problems at ages 60 and 61, and grouping other adults who turned 62 during the calendar year (and thus were not eligible for Social Security during the entire income reporting period) with adults a few years older may understate the protection that Social Security offers. We deal with this complication by excluding 62-year-old respondents from the 1999 and 2001 estimates. To examine how income sources change as people approach retirement, we also compute mean income by source (earnings, employer-sponsored pensions, Social Security, other government transfers, capital income, and other) for this cohort over time. Additionally, we focus on economic outcomes near the bottom of the income distribution by computing mean income for all adults between the 20th and 30th percentiles of the overall distribution and then for those without a high school diploma, who face high risks of economic hardship. 
Another set of tabulations examines how hardship rates for this cohort vary by health status and employment transitions. To measure employment transitions accurately, these tables are based on samples that are restricted to those who respond to the survey at every wave until age 62 (or until they die, if they do not survive to age 62). If we instead categorize workers who respond to only two interviews as consistently working until age 62, for example, we could bias our estimates.

The final piece of descriptive analysis computes the share of adults in the 1937 to 1939 cohort who do not meet our most stringent criterion for financial hardship in 1991 (at ages 52 to 54) and who subsequently experience financial hardship before age 62. We examine how the likelihood of falling into financial hardship varies by gender, race, education, baseline marital status, baseline income, disability status, labor market conditions, and job layoffs. The table also reports the share of adults working full-time at baseline who subsequently experience financial hardship by age 62 .

\section{Models}

The final set of analyses estimates multivariate models of the likelihood of falling into financial hardship. We create a person-year database from 1992 to 2006 of HRS respondents born between 1931 and 1941, and create an indicator of whether the respondent experiences financial hardship (defined as own and spousal income below 100 percent of the official poverty level) in the next wave, conditional on not being in financial hardship in the current wave. We use this measure as the dependent variable in a probit model estimated on the pooled sample of 46,060 observations. We also estimate the models separately for men and women. The independent variables in the model include gender, race, education, marital status, health status, 
spousal characteristics (education, race, and health status), and age dummies. The models also interact the age dummies with health status and interact education with health status.

\section{Results}

Financial hardship rates in 2005 are significantly higher among adults not quite old enough to qualify for Social Security retirement benefits than those eligible for Social Security. About 11 percent of adults ages 60 to 62 receive own and spousal incomes that fall below the federal poverty level, compared with about 8 percent of those ages 63 to 65 . The decline in the hardship rate after age 62 likely reflects the availability of Social Security retirement benefits. Although nearly all Americans qualify for Social Security at age 62, virtually none of the 62year-olds in our 2005 sample receive benefits for the entire calendar year, because payments do not generally begin until two months after one turns 62 (Olson 1999). Hardship rates are somewhat lower at ages 52 to 55 and at ages 56 to 59 than at ages 60 to 62, but the differences are not statistically significant. Hardship rates in the fifties and sixties are especially high among African Americans, Hispanics, people who did not complete high school, and unmarried adults. Additionally, adults with work-limiting health problems are much more likely than those in good health to receive low incomes, and women are more likely than men.

When we use a broader definition of financial hardship—income below 125 percent of the federal poverty level—-the difference in the hardship rate at ages 60 to 62 and ages 63 to 65 narrows and becomes statistically insignificant. About 14 percent of adults ages 60 to 62 have own and spousal incomes that falls below 125 percent of the federal poverty level, compared with about 12 percent of those ages 63 to 65 . The hardship rate declines more modestly after age 62 under this more expansive definition than under the narrower definition considered above 
because Social Security tends to keep beneficiary incomes just above the poverty level. It is less effective at keeping people above 125 percent of the poverty level. Interestingly, hardship rates are nearly 2 percentage points higher at ages 66 to 68 than at ages 63 to 65 under the 125 percent of poverty definition, whereas observed rates are nearly identical at the two ages under the 100 percent of poverty definition. Hardship rates may increase at ages 66 to 68 under the more expansive definition because more people are retired and relying solely on Social Security at ages 66 to 68 than at younger ages. Very few people fall into poverty when their earnings are replaced by Social Security benefits, but some people end up with incomes near the poverty level. As before, hardship rates under this broader measure are especially high among African Americans, Hispanics, those who did not complete high school, and those with health problems.

\section{Trends in Hardship Rates}

There is not an obvious trend in hardship rates from 1991 to 2003 among all adults ages 50 to 55 or all adults ages 56 to 60 (table 2). Under the strict measure, financial hardship rates increase somewhat for the younger group, from 8.7 percent in 1991 to 9.6 percent in 2003, but these differences are not statistically significant. For the older age group, they fluctuate from 10.8 percent in 1991 to 11.5 percent in 1997 to 10.9 percent in 2003. However, hardship rates among adults who did not complete high school increase sharply over the period for both age groups, especially for the younger group. Among adults ages 50 to 55 who lacked a high school diploma, hardship rates nearly double between 1991 and 2003, increasing from about 21 to 39 percent. Although this trend likely reflects eroding job market opportunities for less skilled workers (Goldin and Katz 2007), it probably also reflects changes over time in educational attainment. The share of adults in their fifties who did not complete high school fell sharply from 
1991 to 2003 (Mermin, Johnson, and Murphy 2007). As a result, people in their fifties without high school diplomas represent a relatively more disadvantaged segment of the population in 2003 than in 1991.

\section{Tracking Hardship Rates for the 1937-39 Birth Cohort}

For a better understanding of how hardship evolves as people age from their early fifties to their early sixties and beyond, table 3 shows how the share of adults born between 1937 and 1939 with limited income changes over time. Because we are concerned about how the availability of Social Security affects financial hardship, the analysis excludes respondents when they are age 62, because they can receive Social Security benefits for only part of the observed calendar year (either 1999 or 2001).

Under our strict definition (income less than 100 percent of the poverty level), the overall hardship rate increases steadily as the cohort moves from the early fifties to early sixties, growing from 9.2 percent at ages 52 to 54 to 12.3 percent at ages 60 to 61 , a relative increase of roughly one-third. The pattern reverses after age 62, when people qualify for Social Security retirement benefits, with the hardship rate declining with age. It falls to 10.4 percent at ages 63 to 64 and to 8.5 percent at ages 66 to 68 . These patterns are not simply artifacts of cyclical changes in the overall poverty rate. Between 1991 and 1999, for example, the national poverty rate falls from 14.2 to 11.9 percent, while hardship rates increase for our sample.

Hardship rates grow dramatically for people with limited education as they approach Social Security’s early entitlement age. Among those who did not complete high school, hardship rates increase from 22.6 percent at ages 52 to 54 to 30.8 percent at ages 60 to 61, a relative increase of 36 percent. Hardship rates for those without a high school diploma then fall 
to 24.1 percent at ages 63 to 64 and to 22.3 percent at ages 66 to 68 . However, the share of college graduates with incomes below the federal poverty level does not increase significantly as the cohort approaches age 62, nor does it fall significantly after age 62. Hardship rates also grow substantially from ages 52 to 54 to ages 60 to 61 for Hispanics (from 25.8 to 34.1 percent) and for adults who were unmarried in 2000 (from 19.5 to 28.7 percent). These patterns suggest that some older adults, particularly minorities, unmarried adults, and those with limited education, face increasing financial difficulties as they approach old age, and that Social Security provides important protections for those age 62 and older. ${ }^{3}$

Observed hardship rates also increase as the 1937-39 birth cohort approaches age 62 when we consider a less strict definition (income less than 125 percent of the poverty level). Between ages 52 to 54 and ages 60 to 61, the share of adults with incomes less than 125 percent of the poverty level increases by about one-third, from 11.6 to 15.5 percent. Under this more expansive measure, hardship rates increase significantly in the years before Social Security’s early retirement age for many population groups, including African Americans, non-Hispanic whites, unmarried adults, women, men, high school graduates without a Bachelor's degree, and those who did not complete high school. However, rates do not decline significantly after age 62, falling only to 14.3 percent at ages 64 to 66 and then increasing slightly to 14.5 percent at ages 66 to 68.

\footnotetext{
${ }^{3}$ Including 62-year-olds in the analysis somewhat reduces observed hardship rates in 1999 and somewhat increases them in 2001. Expanding the sample in this way, however, does not change the pattern of rising hardship rates up to age 61 and declining hardship rates thereafter. Details are available from the authors upon request.
} 


\section{Changing Sources of Income Before and After Age 62}

To explore how income falls as people approach age 61, table 4 shows how real mean household income (expressed in constant 20005 dollars) from various sources changes over time. Not surprisingly, real earnings decline sharply as the 1937 to 1939 birth cohort ages from their early fifties to their early sixties. Between ages 52 to 54 and ages 60 to 61, real mean earnings fall by more than $\$ 14,000$ (from about $\$ 36,000$ to about $\$ 22,000$ ). Real mean spouse earnings fall by about another $\$ 9,000$. This $\$ 23,000$ shortfall is almost completely offset by increases in capital income (which partly reflect the strong investment environment in 1999), pension income, and (to a lesser extent) Social Security, most of which comes from older spouses collecting retirement incomes. As a result, real mean household income is nearly identical at ages 52 to 54 and ages 60 to 61 . Mean income falls by about $\$ 12,000$ between ages 60 to 61 and ages 63 to 64 , as own and spouse earnings plunges by another $\$ 12,000$, capital income falls by $\$ 5,000$, and Social Security increases by less than $\$ 8,000$.

Mean household income for people at the lower end of the income distribution falls as they approach age 62, because increases in capital income, pension income, and Social Security are not sufficient to offset the loss in earnings. For those without a high school diploma, mean own and spouse earnings falls by about $\$ 13,000$ between ages 52 to 54 and ages 60 to 61 , while mean household income falls by $\$ 4,000$, a 9 percent decline. Over the same period, mean household income for people between the 20th and 30th percentiles of the income distribution falls by $\$ 6,000$, or 16 percent. And among adults who did not complete high school in the 20th to 30th percentile of the non-high-school-graduate income distribution, mean household income falls by 28 percent as the cohort ages from the early fifties to the early sixties. Their losses are so large because they experience virtually no increases in capital income, pension income, or Social 
Security to offset the decline in earnings as they grow older. However, these low-income groups do not experience very large income declines after age 62, because Social Security replaces a relatively large fraction of their earnings. For example, among those between the 20th and 30th percentiles of the income distribution, household Social Security income at ages 63 to 64 equals 38 percent of own and spouse earnings at ages 52 to 54, compared with only 19 percent for adults at all income levels. For those adults without a high school diploma who fall between the 20th and 30th percentiles of the non-high-school-graduate income distribution, mean household income is higher at ages 63 to 64 than at ages 60 to 61 .

\section{Hardship Rates and Employment Transitions}

Because earnings losses appear to account for much of the increase in economic hardship experienced by people in their late fifties and early sixties, we examine employment transition patterns in the years preceding age 62 for the 1937 to 1939 birth cohort. ${ }^{4}$ One-third of the sample works full-time consistently from ages 53 to 55 to age 62. Nearly another quarter (22.2 percent) works full-time at ages 53 to 55, reduces their labor supply before age 62 (moving to part-time work or no work), and never turns to full-time work. About two-thirds of this group (or 14.5 percent of the entire sample) moves directly from full-time work to no work, and never works again before age 62 . The other third (or 7.9 percent of the entire sample) moves to part-time work before age 62. One-quarter of the full sample works intermittently (working part-time

\footnotetext{
${ }^{4}$ Patterns are quite similar when we examine the larger cohort born between 1937 and 1941.
} 
moving in and out of full-time employment), and the remaining fifth never work between their early fifties and age $62 .^{5}$

Health problems that limit work are quite prevalent among early retirees and those who never work. Nearly three-quarters of those who never work and slightly more than one-half (51.7 percent) of those who move directly out of the labor force from full-time work (and never return to work) report health problems that limit their work ability between ages 53 and 62, compared with about one-third of intermittent workers and about one-sixth of consistent full-time workers. More than one-quarter of early retirees and intermittent workers are displaced from their jobs (through layoffs or business closures) at some point between ages 53 and 62.

Table 6 reports how hardship rates vary by health problems and job layoffs as adults in the 1937 to 1939 birth cohort age from their early fifties to late sixties. Estimates in the table are based on the strict definition of hardship (income below 100 percent of the poverty level). Hardship rates at ages 60 to 61 reach about 13 percent for those who are laid off from a job before age 62, 7 percentage points higher than the rate that prevails at ages 52 to 54 . About 22 percent of adults who report at some point between 1992 and 2000 that health problems limit their work ability experience financial hardship, 5 percentage points higher than at ages 52 to 54 . Health problems boost hardship rates just before Social Security’s early eligibility age most sharply for people with limited education. Among those without a high school diploma who report a health problem that limits their work ability before age 62, hardship rates grow from 32 percent at ages 52 to 54 to 44 percent at ages 60 to 61, a 12 percentage point increase. By

\footnotetext{
${ }^{5}$ Our estimates of work transitions are based only on work status observed at the time of the survey interviews. Respondents who change work status between the interviews but then revert to their old status at the time of the interview are not counted as having made a transition.
} 
contrast, hardship rates do not increase significantly for college graduates who develop work disabilities or for those who did not complete high school and do not report any work disabilities.

The share with incomes below 100 percent of the poverty level falls after age 62 for those with work disabilities, especially those with limited education, another indication of the important role that Social Security plays in protecting economic well-being for people with limited means. For example, only 29 percent of adults with work disabilities who did not complete high school report incomes below the poverty level at ages 66 to 68, 15 percentage points below the share with low incomes at ages 60 to 61 .

Financial hardship rates also increase with age—up to the Social Security early eligibility age-for early retirees (table 7). Among people who work full-time in their early fifties, move directly out of the labor force before age 62, and never work again, the share with incomes below 100 percent of the poverty level increases from about 3 percent at ages 52 to 54 to 17 percent at ages 60 to 61 . Hardship rates then decline for this group once they reach the early eligibility age, falling to 6 percent at ages 64 to 66 . For people who move from full-time work to part-time work before age 62, hardship rates increase from about 4 percent at ages 52 to 54 to about 11 percent at ages 60 to 61 . Hardship rates do not increase significantly as people approach age 62 for those who work full-time until they reach the Social Security early eligibility age or who do not work full-time in 1992 (when they are in their early fifties). Hardship rates are consistently low for people who always work full time, and consistently high for those who never work after their early fifties. However, hardship rates fall substantially after age 62 for those who never work.

Table 8 compares the evolution of hardship rates by employment transition, education, and health. The share of adults with incomes below 100 percent of the poverty level does not increase significantly among people who consistently work full-time through age 62, even for 
those who develop health problems or those with limited education. It also does not increase significantly among people who work intermittently or never work in their fifties, regardless of their health and education. However, hardship rates increase sharply for early retirees with health problems or limited schooling. For example, hardship rates for people without a high school diploma who work full-time in 1992 and permanently left the labor force before age 62 grow from about 9 percent at ages 52 to 54 to 54 percent at ages 60 to 61. During the same period, hardship rates for early retirees increase by about 6 percentage points (to 9 percent) for high school graduates and by about 14 percentage points (to 19 percent) for those who report health problems that limit their ability to work. Hardship rates do not increase significantly for college graduates who permanently leave the labor force before age 62 .

The availability of Social Security retirement benefits at age 62 appears to improve economic well-being substantially for people with limited education or health problems who leave the labor force early. Among early retirees who move directly out of the labor force from full-time work, for example, economic hardship rates fall by 34 percentage points between ages 60 to 61 and ages 64 to 66 for those who did not complete high school and by about 10 percentage points for those with work disabilities.

\section{Transitions into Economic Hardship}

Table 9 shows the share of adults born between 1937 and 1939 who fall into financial hardship (defined as income below the poverty level) before age 62. About 15 percent of all adults with incomes above the poverty level at ages 52 to 54, and 11 percent of full-time workers with incomes above the poverty level, experience economic hardship before reaching the Social Security early eligibility age. These high rates do not merely reflect small income losses by 
adults with baseline incomes only slightly above the poverty level; 11 percent of adults and 9 percent of full-time workers with incomes exceeding 200 percent of the poverty level in 1991 experience a hardship spell before age 62. Financial hardship spells are particularly common for adults with limited education, women, racial minorities, and unmarried adults. For example, about one-third of Hispanics and adults without high school diplomas and more than one-quarter of blacks and unmarried adults experience a pre-62 hardship spell. Health problems, employment shocks, and early labor force withdrawals are also associated with income losses. Almost one in four adults with health-related work limitations suffers hardship spells, compared with only 1 in 10 adults in good health. About one in five adults who works full-time in their early fifties and moves directly out of the labor force before age 62 without any period of part-time work experiences an economic hardship spell before age 62. Similarly, about 27 percent of adults who never work after their early fifties (but do not experience financial hardship at ages 52 to 54) experience a spell of economic hardship before age 62. By contrast, only 5 percent of adults working full-time until age 62 experience hardship spells.

Finally, table 10 reports results from our multivariate models of falling into financial hardship for adults born between 1931 and 1941. On average, adults face a 5.4 percent chance of falling into hardship over a two-year period. Controlling for the overall poverty rate, demographics, and health status, we find that the risk of experiencing financial hardship increases significantly with age for adults in their fifties and early sixties and then declines after age 62. Compared with people ages 51 to 54 , adults ages 57 to 58 are about 1.3 percentage points more likely to fall into hardship, and those ages 59 to 61 are about 1.2 percentage points more likely to fall into hardship. Adults ages 62 and older are significantly less likely to experience hardship than those in their fifties and early sixties. For men (reported in table 11), the risk of 
falling into poverty peaks at ages 59 to 61, whereas for women (reported in table 12) the risk peaks at ages 57 to 58, probably because many women are married to older men who qualify for Social Security before their wives reach age 62 .

As expected, health problems are important predictors of the likelihood of experiencing financial hardship. People who report health-related work limitations are about 4.3 percentage points more likely to fall into hardship than those who do not report health problems. The health impact is larger for those who did not complete high school than for high school graduates. And age has a larger effect on poverty risks for people who develop health problems than for those who do not.

The estimated effects of other demographic variables are not surprising. African Americans and Hispanics are much more likely to experience financial hardship at older ages than non-Hispanic whites, even after other factors are controlled for. Hardship rates decline as educational attainment improves. Women are more likely than men, and single adults are more likely than married adults, to fall into financial hardship. Widowhood and divorce significantly increase the chances of experiencing hardship.

\section{Conclusions}

The likelihood of experiencing financial hardship increases significantly as people approach Social Security's early eligibility age. The share of adults with own and spouse incomes below the poverty level grows by about one-third as people age from their early fifties to their early sixties. The increase in hardship rates is concentrated among low-skilled workers. Among adults who did not complete high school, for example, about 3 in 10 experience financial 
hardship at ages 60 to 61, compared with about 2 in 10 at ages 52 to 54. By contrast, hardship rates for college graduates do not increase significantly as they approach age 62 .

Declines in economic well-being in the late fifties and early sixties are closely tied to work ability. Two-fifths of adults working full-time at ages 52 to 54 reduce their labor supply before age 62; one-fourth completely stop working, leaving the labor force directly from fulltime employment, and another one-seventh move to part-time employment before leaving the labor force. Financial hardship rates more than quadruple between ages 52 to 54 and ages 60 to 61 for workers who exit the labor force early directly from full-time employment. The consequences are particularly serious for those with limited education, more than half of whom report incomes below the poverty level at ages 60 to 61 (up from fewer than 1 in 10 at ages 52 to 54). Many of these departures appear to be at least somewhat involuntary. More than one-quarter of those who move directly out of the labor force from full-time employment have been laid off from a job in their fifties or early sixties, and slightly more than one-half report having a health problem that limits their ability to work. By contrast, fewer than one in six workers employed full-time through age 62 report any work disabilities.

Social Security appears to provide important protections for low-income people. The share of adults experiencing financial hardship declines significantly after age 62, when most people qualify for Social Security retirement benefits. The impact is especially pronounced for people with limited education, who are at greatest risk of falling into poverty. For example, hardship rates for adults who did not complete high school and leave the labor force before Social Security's early eligibility age fall from 54 percent at ages 60 to 61 to 24 percent at ages 63 to 64 to 18 percent at ages 66 to 68 . 
These results highlight the fragility of the income support system for Americans in their fifties and early sixties. Many people who develop health problems as they age fall into poverty before reaching Social Security's early eligibility age. Raising the retirement age would put more people at risk. As lifespans lengthen and physical job demands decline, more and more older Americans are able to work, perhaps justifying an increase in Social Security’s early eligibility age. However, high poverty rates among people in their early sixties with work disabilities reveal the shortcomings in the existing safety net for people with disabilities. Efforts to shore up the disability income system will become even more urgent if the Social Security retirement ages are raised.

\section{References}

Betson, David M, and Robert T. Michael. 1997. "Why So Many Children Are Poor.” The Future of Children 17(2): 25-39.

Blank, Rebecca M., and Mark H. Greenberg. 2008. “Improving the Measurement of Poverty.” Hamilton Project Discussion Paper 2008-17. Washington, DC: Brookings Institution. http://www.brookings.edu/ /media/Files/rc/papers/2008/12_poverty_measurement_blank /12_poverty_measurement_blank.pdf.

Bound, John, Michael Schoenbaum, Todd R. Stinebricker, and Timothy Waidmann. 1998. “The Dynamic Effects of Health on the Labor Force Transitions of Older Workers.” NBER Working Paper 6777. Cambridge, MA: National Bureau of Economic Research.

Bureau of Labor Statistics. 2007. National Compensation Survey: Employee Benefits in Private Industry in the United States, March 2007. Washington, DC: U.S. Department of Labor.

—. 2008. "Labor Force Statistics from the Current Population Survey.” http://data.bls.gov/PDQ/outside.jsp?survey=ln.

Burkhauser, Richard V., Kenneth A. Couch, and John W. Phillips. 1996. "Who Takes Early Social Security Benefits? The Economics and Health Characteristics of Early Beneficiaries.” The Gerontologist 36(6): 789-99.

Butrica, Barbara A., Daniel Murphy, and Sheila R. Zedlewski. 2008. “How Many Struggle to Get By in Retirement?” Retirement Policy Program Discussion Paper 08-01. Washington, DC: Urban Institute. 
Cahill, Kevin E., Giandrea, Michael D., and Joseph F. Quinn. 2005. “Are Traditional

Retirements a Thing of the Past? New Evidence on Retirement Patterns and Bridge Jobs." New York, NY: Tinari Economics Group.

Chan, Sewin, and Ann Huff Stevens. 2001. "Job Loss and Employment Patterns of Older Workers.” Journal of Labor Economics 19(2): 484-521.

Citro, Constance F., and Robert T. Michael. 1995. Measuring Poverty: A New Approach. Washington, DC: National Academy Press.

Coile, Courtney. 2003. “Health Shocks and Couples’ Labor Supply Decisions.” CRR Working Paper No. 2003-08. Chestnut Hill, MA: Center for Retirement Research at Boston College.

Congressional Budget Office. 1999. Raising the Earliest Eligibility Age for Social Security Benefits. Washington, DC: Congressional Budget Office.

- 2004. Disability and Retirement: The Early Exit of Baby Boomers from the Labor Force. Washington, DC: Congressional Budget Office.

Couch, Kenneth A., Nicholas A. Jolly, and Dana W. Placzek. 2009. "Earnings Losses of Older Displaced Workers: A Detailed Analysis with Administrative Data.” Research on Aging 31(1): 17-40.

Englehardt, Gary V., and Jonathan Gruber. 2004. "Social Security and the Evolution of Elderly Poverty.” NBER Working Paper 10466. Cambridge, MA: National Bureau of Economic Research.

Goldin, Claudia, and Lawrence F. Katz. 2007. "Long-Run Changes in the Wage Structure: Narrowing, Widening, Polarizing.” Brookings Papers on Economic Activity 2007(2): 135-65.

Holzer, Harry, Diane Whitmore Schanzenbach, Greg J. Duncan, and Jens Ludwig. 2007. “The Economic Costs of Poverty in the United States: Subsequent Effects of Children Growing Up Poor.” Washington, DC: Center for American Progress.

Hurd, Michael D. 1990. "Research on the Elderly: Economic Status, Retirement, and Consumption.” Journal of Economic Perspectives 28(2): 565-637.

Hurd, Michael D., F. Thomas Juster, and James P. Smith. 2003. "Enhancing the Quality of Data on Income: Recent Innovations from the HRS.” Journal of Human Resources 38(3): 75872.

Johnson, David S., and Timothy M. Smeeding. 2000. "Who Are the Poor Elderly? An Examination Using Alternative Poverty Measures.” CRR Working Paper No. 2000-14. Chestnut Hill, MA: Center for Retirement Research at Boston College. 
Johnson, Richard W., and Melissa M. Favreault. 2001. "Retiring Together or Working Alone: The Impact of Spousal Employment and Disability on Retirement Decisions.” CRR Working Paper No. 2001-01. Chestnut Hill, MA: Center for Retirement Research at Boston College.

Johnson, Richard W., and Anthony T. Lo Sasso. 2006. “The Impact of Elder Care on Women’s Labor Supply at Midlife.” Inquiry 43(3): 195-210.

Johnson, Richard W., Gordon B.T. Mermin, and Dan Murphy. 2007. "The Impact of Late-Career Health and Employment Shocks on Social Security and Pension Wealth.” Washington, DC: The Urban Institute.

Johnson, Richard W., Gordon B.T. Mermin, and Matthew Resseger. 2007. "Employment at Older Ages and the Changing Nature of Work.” AARP Public Policy Institute Report No. 2007-20. Washington, DC: AARP. http://assets.aarp.org/rgcenter/econ/2007_20_work.pdf.

Lahey, Joanna. 2008. “Age, Women, and Hiring: An Experimental Study.” Journal of Human Resources 43(1): 30-56.

Leonesio, Michael V., Denton R. Vaughan, Bernard Wixon. 2000. "Early Retirees Under Social Security: Health Status and Economic Resources.” ORES Working Paper Series Number 86. Washington, DC: Social Security Administration, Office of Research, Evaluation and Statistics.

McGarry, Kathleen. 2004. "Health and Retirement: Do Changes in Health Affect Retirement Expectations?” The Journal of Human Resources 39(3): 624-48.

Mermin, Gordon B.T., Richard W. Johnson, and Dan Murphy. 2006. "Why Do Boomers Plan to Work Longer?” Journal of Gerontology: Social Sciences 62B(5) S286-94.

Munnell, Alicia H., Steven Sass, Mauricio Soto, and Natalia Zhivan. 2006. "Has the Displacement of Older Workers Increased?” CRR Working Paper No. 2006-17. Chestnut Hill, MA: Center for Retirement Research at Boston College. http://crr.bc.edu/images/stories/Working_Papers/wp_2006-17.pdf.

Olson, Janice A. 1999. “Who is ‘62 Enough’? Identifying Respondents Eligible for Social Security Early Retirement Benefits in the Health and Retirement Study.” Social Security Bulletin 62(3): 51-56.

Orshansky, Mollie. 1963. “Children of the Poor.” Social Security Bulletin 26(7): 3-13.

Panis, Constantijn, Michael Hurd, David Loughran, Julie Zissimopoulos, Steven Haider, and Patricia StClair. 2002. “The Effects of Changing Social Security Administration's Early Entitlement Age and the Normal Retirement Age.” DRU-2903-SSA. Santa Monica, CA: RAND. 
Sawhill, Isabel V. 1988. "Poverty in the U.S.: Why Is It So Persistent?” Journal of Economic Literature 26 (3): 1073-19.

Simms, Margaret C., and Daniel Kuehn. 2008. "Unemployment Insurance during a Recession.” Recession and Recovery No. 2. Washington, DC: The Urban Institute.

Smolensky, Eugene, Sheldon Danziger, and Peter Gottschalk. 1988. “The Declining Significance of Age in the United States: Trends in the Well-Being of Children and the Elderly Since 1939.” In The Vulnerable, edited by John L. Palmer, Timothy Smeeding, and Barbara Boyle Torrey. Washington, DC: Urban Institute Press. 
Table 1. Share of Older Americans Experiencing Financial Hardship, by Age and Other Characteristics, 2005

\begin{tabular}{|c|c|c|c|c|c|}
\hline & & & Age & & \\
\hline & $52-55$ & 56-59 & $60-62$ & 63-65 & $66-68$ \\
\hline Percentage & sehold Ince & Below the & deral Pove & Level & \\
\hline All & 9.5 & 9.8 & 11.1 & $8.1^{* *}$ & $8.5^{*}$ \\
\hline Gender & & & & & \\
\hline Men & 7.8 & 6.8 & 9.2 & $5.4 * *$ & $5.0 * *$ \\
\hline Women & 11.0 & 12.6 & 12.9 & 10.7 & 11.5 \\
\hline Race and Ethnicity & & & & & \\
\hline African American & 21.7 & 26.2 & 26.1 & 22.6 & 28.4 \\
\hline Hispanic & 23.9 & 23.8 & 34.0 & 25.0 & 34.5 \\
\hline Non-Hispanic white, other & 6.2 & 6.6 & 6.9 & 5.1 & $4.4^{* *}$ \\
\hline Education & & & & & \\
\hline Did not complete high school & 29.5 & 31.0 & 31.3 & $22.7 * *$ & $22.2 * *$ \\
\hline High school graduate & 8.6 & 9.2 & 8.6 & $5.8^{*}$ & 6.0 \\
\hline College graduate & 4.5 & 3.2 & 4.8 & $1.6^{*}$ & $2.0^{*}$ \\
\hline Marital Status & & & & & \\
\hline Married & 4.6 & 4.5 & 5.0 & 3.6 & $3.3^{*}$ \\
\hline Not married & 24.7 & 25.7 & 27.1 & $19.6^{* *}$ & 21.1 \\
\hline Health Status & & & & & \\
\hline Problem that limits work & 25.3 & 22.3 & 20.8 & $15.7 *$ & 16.0 \\
\hline No work-limiting problem & 5.4 & 5.6 & 6.9 & $4.8^{*}$ & 5.3 \\
\hline Percentage with & d Income & w $125 \%$ & le Federal & verty Leve & \\
\hline All & 12.1 & 12.5 & 14.4 & 12.4 & 14.2 \\
\hline Gender & & & & & \\
\hline Men & 10.7 & 9.6 & 12.0 & 9.2 & 9.9 \\
\hline Women & 13.5 & 15.2 & 16.7 & 15.4 & 17.8 \\
\hline Race and Ethnicity & & & & & \\
\hline African American & 25.7 & 30.7 & 33.8 & 26.8 & 36.2 \\
\hline Hispanic & 29.6 & 26.7 & 35.5 & 35.7 & 47.7 \\
\hline Non-Hispanic white, other & 8.3 & 9.1 & 9.9 & 8.9 & 9.2 \\
\hline Education & & & & & \\
\hline Did not complete high school & 38.5 & 37.1 & 38.0 & 32.6 & 33.5 \\
\hline High school graduate & 11.0 & 12.2 & 12.0 & 9.7 & 11.2 \\
\hline College graduate & 5.5 & 3.9 & 5.9 & 2.2 & 2.9 \\
\hline Marital Status & & & & & \\
\hline Married & 6.5 & 6.7 & 7.5 & 6.3 & 6.3 \\
\hline Not married & 29.8 & 29.9 & 32.7 & 28.1 & 32.9 \\
\hline Health Status & & & & & \\
\hline Problem that limits work & 33.0 & 28.0 & 26.1 & 24.0 & 25.9 \\
\hline No work-limiting problem & 6.8 & 7.3 & 9.4 & 7.3 & 9.1 \\
\hline Number of observations & 2,074 & 1,905 & 1,353 & 2,036 & 2,015 \\
\hline
\end{tabular}

Source: Authors' computations from the 2006 HRS.

Note: Estimates for all age groups use poverty thresholds for households younger that 65 . Marital status and health status are measured in 2006. Asterisks indicate that estimates differ significantly from the age-60-to-62 estimates (* $.05<p<.1, * * p<.05)$ 
Table 2. Trends in the Percentage of Adults Ages 50 to 60 Experiencing Financial Hardship, 1991, 1997, and 2003

\begin{tabular}{|c|c|c|c|c|c|c|}
\hline & \multicolumn{3}{|c|}{ Ages 50 to 55} & \multicolumn{3}{|c|}{ Ages 56 to 60} \\
\hline & 1991 & 1997 & 2003 & 1991 & 1997 & 2003 \\
\hline \multicolumn{7}{|c|}{ Percentage with Household Income Below the Federal Poverty Level } \\
\hline All & 8.7 & 9.5 & 9.6 & 10.8 & 11.5 & 10.9 \\
\hline \multicolumn{7}{|l|}{ Gender } \\
\hline Men & 6.3 & 7.0 & $8.6^{* *}$ & 8.3 & 8.9 & 8.3 \\
\hline Women & 10.8 & 11.6 & 10.6 & 13.0 & 13.9 & 13.4 \\
\hline \multicolumn{7}{|l|}{ Race and Ethnicity } \\
\hline African-American & 19.9 & 22.5 & 22.3 & 25.0 & 25.9 & 25.5 \\
\hline Hispanic & 23.7 & 24.6 & 27.4 & 28.3 & 27.7 & 24.1 \\
\hline Non-Hispanic white, other & 6.0 & 6.6 & 5.7 & 7.9 & 8.3 & 7.9 \\
\hline \multicolumn{7}{|l|}{ Education } \\
\hline Did not complete high school & 20.8 & $30.7^{* *}$ & $39.1^{* *}$ & 22.0 & $28.0 * *$ & $31.5^{* *}$ \\
\hline High school graduate & 6.4 & 7.1 & 7.7 & 7.7 & 8.5 & $9.9 *$ \\
\hline College graduate & 2.0 & 3.0 & 3.0 & 4.6 & 2.8 & $2.3^{* *}$ \\
\hline \multicolumn{7}{|l|}{ Marital Status } \\
\hline Married & 5.1 & 5.7 & 5.5 & 5.9 & 6.7 & 5.4 \\
\hline Not married & 20.8 & 20.0 & 21.5 & 26.3 & 26.2 & 26.4 \\
\hline \multicolumn{7}{|l|}{ Health Status } \\
\hline Problem that limits work & 22.2 & 25.3 & 24.7 & 24.2 & 25.5 & 23.5 \\
\hline No work-limiting problem & 5.7 & 5.6 & 5.6 & 6.6 & 7.0 & $5.3^{*}$ \\
\hline
\end{tabular}

Percentage with Household Income Below $125 \%$ of the Federal Poverty Level

\begin{tabular}{lrrrrrr} 
All & 11.1 & 11.6 & 11.9 & 14.0 & 14.8 & 13.6 \\
Gender & & & & & & \\
$\quad$ Men & 8.3 & 9.2 & 10.5 & 11.1 & 11.2 & 9.8 \\
$\quad$ Women & 13.6 & 13.7 & 13.2 & 16.6 & 18.0 & 17.0 \\
$\quad$ Race and Ethnicity & & & & & & \\
$\quad$ African-American & 24.4 & 24.4 & 25.2 & 32.7 & 33.6 & 31.4 \\
$\quad$ Hispanic & 30.8 & 28.7 & 31.0 & 32.8 & 33.0 & 28.2 \\
$\quad$ Non-Hispanic white, other & 7.8 & 8.6 & 7.7 & 10.5 & 10.8 & 10.0 \\
Education & & & & & & \\
$\quad$ Did not complete high school & 26.6 & $36.4^{* *}$ & $44.3^{* *}$ & 29.3 & $33.9 *$ & $37.5^{* *}$ \\
$\quad$ High school graduate & 8.3 & 8.9 & $10.2^{*}$ & 9.8 & 11.7 & 12.2 \\
$\quad$ College graduate & 2.3 & 3.8 & 3.8 & 5.4 & 3.6 & 3.9 \\
$\quad$ Marital Status & & & & & & \\
$\quad$ Married & 6.9 & 7.4 & 6.3 & 8.3 & 9.2 & 7.2 \\
$\quad$ Not married & 25.4 & 23.3 & 28.1 & 32.2 & 31.6 & 31.2 \\
Health Status & & & & & & \\
$\quad$ Problem that limits work & 27.7 & 28.7 & 30.8 & 30.2 & 33.2 & 27.8 \\
$\quad$ No work-limiting problem & 7.4 & 7.4 & 6.9 & 9.0 & 8.8 & $7.2^{* *}$ \\
$\quad$ Number of observations & 5568 & 3310 & 3380 & 4051 & 3976 & 2338 \\
\hline
\end{tabular}

Source: Authors' computations from the 1992, 1998, and 2004 HRS.

Note: Estimates for all age groups use poverty thresholds for households younger that 65. Marital status and health status are measured in the following year. Asterisks indicate that estimates differ significantly from 1991 estimates $\left(* .05<p<.1,{ }^{* *} p<.05\right)$ 
Table 3. Percentage of Adults Born Between 1937 and 1939 Experiencing Financial Hardship, by Year

\begin{tabular}{lcccccccc}
\hline & $\mathbf{1 9 9 1}$ & $\mathbf{1 9 9 3}$ & $\mathbf{1 9 9 5}$ & $\mathbf{1 9 9 7}$ & $\mathbf{1 9 9 9}$ & $\mathbf{2 0 0 1}$ & $\mathbf{2 0 0 3}$ & $\mathbf{2 0 0 5}$ \\
\hline National Poverty Rate, all ages & 14.2 & 15.1 & 13.8 & 13.3 & 11.9 & 11.7 & 12.5 & 12.6 \\
Age Range, 1937-1939 Cohort & $52-54$ & $54-56$ & $56-58$ & $58-60$ & $60-61$ & $63-64$ & $64-66$ & $66-68$
\end{tabular}

Percentage with Household Income Below the Federal Poverty Level

$\begin{array}{lcccccccc}\text { All } & 9.2^{* *} & 9.5^{* *} & 9.7^{* *} & 12.1 & 12.3 & 10.4 & 9.5^{* *} & 8.5^{* *} \\ & & & & & & & & \\ \text { Gender } & & & & & & & & \\ \quad \text { Men } & 6.7 & 7.7 & 7.4 & 8.8 & 8.7 & 6.6 & 6.1^{*} & 5.1^{* *} \\ \quad \text { Women } & 11.6^{* *} & 11.3^{* *} & 11.9^{* *} & 15.1 & 15.6 & 13.5 & 12.6^{*} & 11.5^{* *} \\ & & & & & & & & \\ \text { Race and Ethnicity } & & & & & & & & \\ \quad \text { African American } & 19.9 & 19.6 & 20.7 & 24.6 & 25.7 & 21.6 & 24.4 & 27.8 \\ \quad \text { Hispanic } & 25.8^{*} & 27.6 & 31.3 & 30.9 & 34.1 & 33.9 & 32.4 & 32.0 \\ \quad \text { Non-Hispanic white, other } & 6.5^{*} & 6.9 & 6.5^{*} & 8.8 & 8.5 & 6.7 & 6.2^{* *} & 4.6^{* *} \\ & & & & & & & & \\ \text { Education } & & & & & & & & \\ \quad \text { Did not complete high school } & 22.6^{* *} & 24.7^{*} & 25.4^{*} & 29.3 & 30.8 & 24.1^{*} & 22.5^{* *} & 22.3^{* *} \\ \quad \begin{array}{l}\text { High school graduate } \\ \quad \text { College graduate }\end{array} & 6.3^{* *} & 6.7 & 6.2^{* *} & 8.5 & 8.7 & 7.4 & 7.4 & 5.7^{* *} \\ \quad & 1.9 & 1.1 & 1.8 & 3.0 & 1.9 & 3.5 & 1.7 & 2.2 \\ \quad \begin{array}{l}\text { Marital Status, 2000 } \\ \quad \text { Married }\end{array} & & & & & & & & \\ \quad \text { Not married } & 6.7 & 6.9 & 6.4 & 8.0^{*} & 6.3 & 6.1 & 5.8 & 4.9 \\ \quad & 19.5^{* *} & 19.4^{* *} & 21.4^{* *} & 25.2 & 28.7 & 23.4 & 21.5^{* *} & 20.4^{* *}\end{array}$

Percentage with Household Income Below 125\% of the Federal Poverty Level

\begin{tabular}{|c|c|c|c|c|c|c|c|c|}
\hline All & $11.6^{* *}$ & $12.0^{* *}$ & $12.3^{* *}$ & 15.5 & 15.5 & 14.6 & 14.3 & 14.5 \\
\hline \multicolumn{9}{|l|}{ Gender } \\
\hline Men & $8.8^{*}$ & 9.5 & 9.9 & 11.2 & 11.3 & 9.3 & 10.8 & 10.6 \\
\hline Women & $14.2^{* *}$ & $14.3^{* *}$ & $14.6^{* *}$ & 19.4 & 19.3 & 19.1 & 17.4 & 17.9 \\
\hline \multicolumn{9}{|l|}{ Race and Ethnicity } \\
\hline African-American & $25.7 * *$ & $23.5^{* *}$ & $24.4 * *$ & 33.2 & 33.8 & 29.1 & 33.7 & 37.5 \\
\hline Hispanic & 31.2 & 34.2 & 35.8 & 36.8 & 37.9 & 42.3 & 39.5 & 46.2 \\
\hline Non-Hispanic white, other & $8.1^{* *}$ & $8.9 *$ & $8.8 *$ & 11.4 & 11.0 & 10.1 & 10.3 & 9.5 \\
\hline \multicolumn{9}{|l|}{ Education } \\
\hline Did not complete high school & $27.8 * *$ & $28.5^{* *}$ & 31.8 & 36.5 & 36.5 & 31.3 & 32.8 & 34.6 \\
\hline High school graduate & $8.1^{* *}$ & $9.3^{*}$ & $8.2^{* *}$ & 11.3 & 11.7 & 11.6 & 11.5 & 11.1 \\
\hline College graduate & 2.6 & 1.5 & 1.8 & 3.5 & 2.6 & 4.4 & 2.6 & 3.0 \\
\hline \multicolumn{9}{|l|}{ Marital Status, 2000} \\
\hline Married & 8.6 & 8.9 & 8.7 & $10.5^{*}$ & 8.3 & 8.9 & 9.1 & 8.8 \\
\hline Not married & $23.4^{* *}$ & $23.7^{* *}$ & $25.3^{* *}$ & 31.4 & 34.9 & 32.2 & 31.0 & 33.2 \\
\hline Number of observations & 2830 & 2520 & 2394 & 2287 & 1439 & 1378 & 2035 & 1926 \\
\hline
\end{tabular}

Source: Authors' computations from the 1992 to 2006 waves of the HRS.

Note: Estimates for all age groups use poverty thresholds for households younger that 65. The 1999 and 2001 samples exclude respondents age 62. Asterisks indicate that estimates differ significantly from 1999 estimates $(* .05$ $<p<.1, * * p<.05)$ 
Table 4. Real Mean Household Income for Adults Born Between 1937 and 1939, by Year (2005 Dollars)

\begin{tabular}{|c|c|c|c|c|c|c|c|c|}
\hline & 1991 & 1993 & 1995 & 1997 & 1999 & 2001 & 2003 & 2005 \\
\hline Age Range & $52-54$ & $54-56$ & $56-58$ & $58-60$ & $60-61$ & $63-64$ & $64-66$ & $66-68$ \\
\hline \multicolumn{9}{|l|}{ All Adults } \\
\hline Total & $\$ 77,715$ & $\$ 82,663$ & $\$ 81,152$ & $\$ 80,267$ & $\$ 77,433$ & $\$ 65,512$ ** & $\$ 70,198$ * & $\$ 67,397$ \\
\hline Respondent Earnings & 36,256 ** & 33,591 ** & 28,464 ** & 26,447 * & 21,728 & 16,008 * & 12,241 ** & 8,879 ** \\
\hline Spouse Earnings & 24,036 ** & 21,827 ** & 18,784 ** & 15,912 & 15,075 & 8,544 ** & 9,102 ** & 6,652 ** \\
\hline Pensions & 1,954 ** & 4,133 * & $4,810 * *$ & $5,645 * *$ & 7,143 & 8,353 & $9,441 * *$ & 10,841 ** \\
\hline Social Security & $1,167 * *$ & $1,445 * \star$ & $2,163 * *$ & $3,001 * *$ & 3,814 & 11,284 ** & 14,553 ** & 17,084 ** \\
\hline Unemployment/Gov Transfers & 1,512 & 1,295 & 1,601 & 1,596 & 1,576 & 1,285 & 1,272 & 1,263 \\
\hline Capital Income & $9,355 * *$ & $16,377 \star \star$ & 23,449 & 23,395 & 23,413 & 18,192 * & $17,367 * *$ & $15,392 * *$ \\
\hline Other Income & 3,435 & 3,995 & 1,881 * & 4,271 & 4,683 & 1,846 * & 6,223 & 7,285 \\
\hline Number of Observations & 2830 & 2520 & 2394 & 2287 & 1439 & 1378 & 2035 & 1926 \\
\hline \multicolumn{9}{|c|}{ Adults in the 20th - 30th Percentiles of Income } \\
\hline Total & $\$ 35,538$ ** & $\$ 34,994 * *$ & $\$ 34,445$ ** & $\$ 30,681$ & $\$ 29,888$ & $\$ 26,511$ * & $\$ 27,348$ & $\$ 25,160$ ** \\
\hline Respondent Earnings & 19,231 ** & $17,495 * *$ & 13,706 & 12,408 & 12,342 & 6,692 ** & 4,183 ** & 1,756 ** \\
\hline Spouse Earnings & 8,306 ** & $6,953 *$ & 4,954 & 4,336 & 3,307 & 1,466 * & 1,952 & 741 ** \\
\hline Pensions & $2,109 * *$ & 3,727 & 3,689 & 4,480 & 5,179 & 3,985 & 4,838 & 3,950 \\
\hline Social Security & 2,402 ** & 2,370 ** & 3,955 & 3,773 & 4,527 & 10,434 ** & 13,395 ** & 14,965 ** \\
\hline Unemployment/Gov Transfers & 1,284 & 1,151 & 965 & 1,129 & 764 & 495 & 734 & 953 \\
\hline Capital Income & 1,424 ** & 2,549 & $6,558 * *$ & 4,070 & 3,251 & 3,169 & 1,918 * & 2,677 \\
\hline Other Income & 782 & 749 & 617 & 485 & 518 & 270 & 328 & 118 \\
\hline Number of Observations & 293 & 259 & 248 & 223 & 149 & 143 & 211 & 195 \\
\hline \multicolumn{9}{|c|}{ Adults with Less than High School Education } \\
\hline Total & $\$ 42,308$ & $\$ 38,261$ & $\$ 37,920$ & $\$ 39,207$ & $\$ 38,517$ & $\$ 40,034$ & $\$ 36,613$ & $\$ 36,624$ \\
\hline Respondent Earnings & 17,852 ** & 14,808 ** & 12,340 & 11,294 & 10,017 & 8,112 & 5,022 ** & 4,155 ** \\
\hline Spouse Earnings & 13,727 ** & $12,344 * *$ & 10,756 * & 7,997 & 8,408 & 4,667 * & $5,055 * *$ & 4,106 ** \\
\hline Pensions & 713 ** & 1,482 ** & 1,967 & 2,179 & 2,847 & 3,720 & $4,120 *$ & 3,748 \\
\hline Social Security & 1,741 ** & 2,189 ** & 3,106 ** & 3,822 * & 4,697 & 10,645 ** & 12,897 ** & 14,446 ** \\
\hline Unemployment/Gov Transfers & 1,672 * & 1,550 & 1,164 & 1,336 & 1,131 & 815 & 719 & 755 \\
\hline Capital Income & 5,643 & 5,009 * & 8,009 & 10,394 & 10,839 & 10,079 & 7,903 & 8,450 \\
\hline Other Income & 960 & 878 & 578 & $2,185 * *$ & 577 & 1,996 & 898 & 965 \\
\hline Number of Observations & 745 & 623 & 615 & 580 & 363 & 349 & 517 & 477 \\
\hline \multicolumn{9}{|c|}{ Adults with Less than High School Education in the 20th - 30th Percentiles of Income } \\
\hline Total & $\$ 14,566$ ** & $\$ 13,534$ ** & $\$ 12,212$ ** & $\$ 10,773$ & $\$ 10,417$ & $\$ 12,770$ * & $\$ 12,879 * *$ & $\$ 12,769$ ** \\
\hline Respondent Earnings & $5,664 * *$ & 4,303 & 2,716 & 1,967 & 2,566 & 1,329 & 1,018 * & 75 ** \\
\hline Spouse Earnings & 1,312 * & 1,271 & 391 & 617 & 483 & 0 * & 181 & 235 \\
\hline Pensions & 697 & 776 & 369 & 908 * & 135 & 347 & 243 & 390 \\
\hline Social Security & 4,870 & $3,802 *$ & 6,024 & 5,254 & 5,835 & 10,147 ** & 10,684 ** & 11,495 ** \\
\hline Unemployment/Gov Transfers & $1,410 * *$ & 2,464 ** & 902 & 547 & 581 & 400 & 435 & 238 * \\
\hline Capital Income & 363 & 483 & 1,505 & 1,207 & 815 & 325 & 88 * & 324 \\
\hline Other Income & 249 & 435 * & 305 & 272 & 3 & 221 & 231 & 12 \\
\hline Number of Observations & 78 & 59 & 58 & 52 & 37 & 40 & 53 & 48 \\
\hline
\end{tabular}

Source: Authors' estimates from the 1992 - 2006 waves of the Health and Retirement Study

Notes: 20th-30th percentile for adults with less than high school education refers to the income distribution for the less-than-high-school group. The 1999 and 2001 samples exclude respondents age 62 . Asterisks indicate that amounts differ significantly from those for $1999(* .05<p<.1, \star \star$ $p<.05)$. 
Table 5. Size and Characteristics of Labor Force Transition Groups, Adults Born Between 1937 and 1939

\begin{tabular}{|c|c|c|c|c|c|c|c|c|c|c|}
\hline & \multirow[b]{2}{*}{ All } & \multicolumn{5}{|c|}{ Work Full-Time in 1992} & \multirow{2}{*}{\multicolumn{2}{|c|}{$\begin{array}{l}\text { Intermittent } \\
\text { Workers }\end{array}$}} & \multirow{2}{*}{\multicolumn{2}{|c|}{ Never Work }} \\
\hline & & $\begin{array}{c}\text { Continue Through } \\
\text { Age } 62\end{array}$ & $\begin{array}{r}\text { Move Dire } \\
\text { Zero Hours } \\
62\end{array}$ & $\begin{array}{l}\text { ectly to } \\
\text { Before }\end{array}$ & $\begin{array}{r}\text { Move to Part } \\
\text { Work Before } 6 \\
\text { Return to }\end{array}$ & $\begin{array}{l}\text { t-Time } \\
\text { 2, Never } \\
\text { FT }\end{array}$ & & & & \\
\hline Share of Population & 100.0 & 33.3 & 14.3 & & 7.9 & & 25.4 & & 19.1 & \\
\hline \multicolumn{11}{|l|}{ Gender } \\
\hline Female & 52.0 & 35.3 & 43.7 & $\star *$ & 49.0 & $\star *$ & 66.1 & ** & 70.0 & $\star *$ \\
\hline Male & 48.0 & 64.7 & 56.3 & $* *$ & 51.0 & * & 33.9 & ** & 30.0 & ** \\
\hline \multicolumn{11}{|l|}{ Education } \\
\hline Less Than High School & 21.5 & 17.4 & 21.7 & & 12.5 & & 20.1 & & 34.2 & $\star \star$ \\
\hline High School Graduate & 60.3 & 59.3 & 56.2 & & 67.8 & * & 63.2 & & 57.9 & \\
\hline College Graduate & 18.2 & 23.3 & 22.1 & & 19.7 & & 16.7 & $\star \star$ & 7.9 & $* *$ \\
\hline \multicolumn{11}{|l|}{ Race and Ethnicity } \\
\hline African American & 9.6 & 7.3 & 9.7 & & 9.8 & & 9.5 & & 13.9 & $\star *$ \\
\hline Hispanic & 6.9 & 5.2 & 7.0 & & 9.1 & & 7.5 & * & 8.4 & ** \\
\hline Non-Hispanic White, Other & 83.4 & 87.6 & 83.2 & * & 81.2 & * & 83.0 & ** & 77.8 & ** \\
\hline \multicolumn{11}{|l|}{1992 Marital Status } \\
\hline Unmarried & 21.6 & 20.4 & 29.6 & $\star *$ & 20.4 & & 17.8 & & 23.1 & \\
\hline Married & 78.4 & 79.6 & 70.4 & ** & 79.6 & & 82.2 & & 76.9 & \\
\hline \multicolumn{11}{|l|}{ Laid Off Before 62} \\
\hline No & 82.1 & 89.4 & 71.0 & $\star *$ & 74.2 & $\star \star$ & 71.1 & ** & 95.7 & ** \\
\hline Yes & 17.9 & 10.6 & 29.0 & ** & 25.8 & $\star \star *$ & 28.9 & ** & 4.3 & $\star *$ \\
\hline \multicolumn{11}{|l|}{ Health Limits Work Before 62} \\
\hline No & 60.4 & 84.1 & 48.3 & ** & 56.4 & ** & 62.3 & $\star \star$ & 27.0 & $\star \star$ \\
\hline Yes & 39.6 & 15.9 & 51.7 & ** & 43.6 & $\star \star$ & 37.7 & ** & 73.0 & ** \\
\hline \multicolumn{11}{|l|}{$\begin{array}{l}\text { Health Limits Work or Laid Off } \\
\text { Before } 62\end{array}$} \\
\hline No & 48.9 & 75.0 & 32.8 & ** & 43.2 & $\star \star$ & 43.2 & ** & 25.1 & $* *$ \\
\hline Yes & 51.1 & 25.0 & 67.2 & ** & 56.8 & $\star \star$ & 56.8 & $\star \star$ & 74.9 & $\star \star$ \\
\hline Number of observations & 2080 & 669 & 294 & & 159 & & 526 & & 432 & \\
\hline
\end{tabular}

Source: Authors' estimates from the 1992 - 2006 waves of the Health and Retirement Study.

Note: The sample is restricted to respondents who were interviewed in 1992 and completed each interview through age 62 or until they died. Asterisks indicate that percentages differ significantly from those for adults working full-time through age $62\left({ }^{\star} .05<p<.1,{ }^{\star \star} p<.05\right)$. 
Table 6. Percentage of Adults Born Between 1937 and 1939 Experiencing Financial Hardship, by Layoff Status, Health, Education, and Year

\begin{tabular}{|c|c|c|c|c|c|c|c|c|}
\hline & 1991 & 1993 & 1995 & 1997 & 1999 & 2001 & 2003 & 2005 \\
\hline Age Range & $52-54$ & $54-56$ & $56-58$ & $58-60$ & $60-61$ & $63-64$ & $64-66$ & $66-68$ \\
\hline Laid Off Before Age 62 & $6.4 * \star$ & $7.9 *$ & $8.2 *$ & 12.9 & 12.7 & 11.1 & $7.9 *$ & 8.9 \\
\hline Health Limits Work Before Age 62 & 17.2 ** & $16.6 * *$ & 18.0 * & 20.2 & 22.4 & 18.7 & 17.3 ** & $14.3 * *$ \\
\hline \multicolumn{9}{|l|}{ Health Never Limits Work } \\
\hline Less Than High School & 13.0 & 17.0 & 15.5 & 17.7 & 17.3 & 16.6 & 15.0 & 16.3 \\
\hline High School Graduate & 2.8 & 3.4 & 2.5 * & 5.8 & 4.4 & 3.3 & 3.8 & 3.4 \\
\hline College Graduate & 1.7 & 1.4 & 1.0 & 2.3 & 1.5 & 3.2 & 1.0 & 2.0 \\
\hline \multicolumn{9}{|l|}{ Health Limits Work Before Age 62} \\
\hline Less Than High School & 32.4 ** & $31.9 * \star$ & 34.9 * & 40.8 & 43.8 & 33.4 * & 30.8 ** & $28.7 * \star$ \\
\hline High School Graduate & 12.2 & 12.1 & 12.0 & 12.7 & 15.5 & 14.4 & 13.4 & $9.7 * *$ \\
\hline College Graduate & 2.6 & 0.0 & 4.7 & 5.5 & 3.0 & 4.7 & 4.6 & 3.0 \\
\hline Number of observations & 2830 & 2520 & 2394 & 2287 & 1439 & 1378 & 2035 & 1926 \\
\hline
\end{tabular}

Source: Authors' estimates from the 1992 - 2006 waves of the Health and Retirement Study.

Notes: Financial hardshipis defined as having own and spousal income below 100 percent of the federal poverty level. Estimates for all age groups use poverty thresholds for households younger that 65 . The 1999 and 2001 samples exclude respondents age 62 . Asterisks indicate that estimates differ signific antly from 1999 estimates $\left({ }^{*} .05<p<.1,{ }^{*} p<.05\right)$ 
Table 7. Percentage of Adults Born Between 1937 and 1939 Experiencing Financial Hardship, by Labor Force Transition and Year

\begin{tabular}{|c|c|c|c|c|c|c|c|c|}
\hline & 1991 & 1993 & 1995 & 1997 & 1999 & 2001 & 2003 & 2005 \\
\hline Age Range & $52-54$ & $54-56$ & $56-58$ & $58-60$ & $60-61$ & $63-64$ & $64-66$ & $66-68$ \\
\hline \multicolumn{9}{|l|}{ Worked Full-Time in 1992} \\
\hline Continue Through Age 62 & 2.1 & 2.2 & 1.0 & 1.9 & 1.7 & 3.2 & $4.2 * *$ & 2.9 \\
\hline \multicolumn{9}{|l|}{ Move Directly to Zero Hours Before } \\
\hline 62 & 3.4 ** & $4.8 * *$ & $9.9 * *$ & 12.1 & 16.7 & 11.2 & 6.2 ** & $7.5 * *$ \\
\hline $\begin{array}{l}\text { Move to Part-Time Work before } \\
\text { Never Return to Full-Time Work }\end{array}$ & 3.8 * & 4.5 * & $4.2 *$ & 5.7 & 10.5 & 5.1 & 7.3 & 4.0 \\
\hline Intermittent Work & 10.6 & 10.7 & 8.6 & 12.1 & 9.8 & 10.4 & 7.8 & 8.5 \\
\hline Never Work & 25.4 & 25.4 & 23.6 & 25.9 & 28.2 & 21.0 & 23.0 & 18.0 ** \\
\hline Number of observations & 2080 & 2040 & 1994 & 1947 & 1234 & 1195 & 1719 & 1638 \\
\hline
\end{tabular}

Source: Authors' estimates from the 1992 - 2006 waves of the Health and Retirement Study.

Notes: Financial hardship is defined as having own and spousal income below 100 percent of the federal poverty level. Estimates for all age groups use poverty thresholds for households younger that 65. The sample is restricted to respondents who were interviewed in 1992 and completed each interview through age 62 or until they died. The 1999 and 2001 samples exclude respondents age 62. Asterisks indicate that estimates differ signific antly from 1999 estimates $\left(* .05<p<.1,{ }^{*} p<.05\right)$ 
Table 8. Percentage of Adults Born Between 1937 and 1939 Experiencing Financial Hardship, by Employment Status, Health,

Education, and Year

\begin{tabular}{|c|c|c|c|c|c|c|c|c|}
\hline & 1991 & 1993 & 1995 & 1997 & 1999 & 2001 & 2003 & 2005 \\
\hline Age Range & $52-54$ & $54-56$ & $56-58$ & $58-60$ & $60-61$ & $63-64$ & 64-66 & $66-68$ \\
\hline \multicolumn{9}{|l|}{ Full-Time Through Age 62} \\
\hline Health Limits W ork Before Age 62 & 1.3 & 1.6 & 0.0 & 0.0 & 0.8 & 4.8 & 4.6 * & 2.8 \\
\hline Less Than High School & 6.9 & 7.7 & 2.6 & 2.9 & 5.3 & 9.5 & 10.6 & 10.8 \\
\hline High School Graduate & 1.4 & 0.8 & 1.0 & 2.4 & 1.4 & 2.2 & 4.2 ** & 2.0 \\
\hline College Graduate & 0.0 & 2.0 * & 0.0 & 0.0 & 0.0 & 0.5 & 0.0 & 0.0 \\
\hline \multicolumn{9}{|l|}{$\begin{array}{l}\text { Full-Time in 1992, Move Directly to } \\
\text { Zero Hours Before } 62\end{array}$} \\
\hline Health Limits W ork Before Age 62 & $5.1 * *$ & 5.7 ** & 14.3 & 12.8 & 19.0 & 15.3 & $8.9 * \star$ & 10.4 * \\
\hline Less Than High School & 8.8 ** & 15.7 ** & 32.1 ** & 33.6 ** & 53.8 & $24.1 * \star$ & 19.5 ** & 18.3 ** \\
\hline High School Graduate & 2.7 * & 2.6 * & 3.9 & 7.0 & 8.6 & 7.9 & 2.5 * & 2.9 * \\
\hline College Graduate & 0.0 & 0.0 & 4.6 & 5.1 & 5.2 & 7.5 & 3.6 & 9.2 \\
\hline \multicolumn{9}{|l|}{ Full-Time in 1992, Move to Part- } \\
\hline \multicolumn{9}{|l|}{ Time Work Before 62} \\
\hline Health Limits W ork Before Age 62 & 7.6 & 6.3 & $3.9 * *$ & 6.4 & 16.6 & 6.8 & $3.5 * *$ & 2.5 ** \\
\hline Less Than High School & 17.1 & 14.6 * & 10.2 ** & 28.7 & 39.0 & 30.9 & 23.4 & 13.3 * \\
\hline High School Graduate & 2.6 & 4.0 & 4.3 & 3.2 & 7.3 & 1.7 & 5.5 & 3.6 \\
\hline College Graduate & 0.0 & 0.0 & 0.0 & 0.0 & 0.0 & 0.0 & 2.7 & 0.0 \\
\hline \multicolumn{9}{|l|}{ Intermittent Workers } \\
\hline Health Limits Work Before Age 62 & 17.1 & 14.6 & 14.6 & 19.9 & 17.0 & 17.3 & 14.1 & 12.8 \\
\hline Less Than High School & 24.0 & 26.8 & 22.3 & 26.5 & 23.0 & 24.2 & 20.1 & 20.4 \\
\hline High School Graduate & 8.0 & 8.5 & 5.8 & 9.5 & 7.7 & 8.4 & 5.8 & 6.2 \\
\hline College Graduate & 4.8 * & 0.3 & 2.9 & 4.3 * & 0.0 & $4.8 *$ & 1.8 & 2.9 \\
\hline \multicolumn{9}{|l|}{ Never Work } \\
\hline Health Limits Work Before Age 62 & 30.7 & 31.2 & 29.6 & 32.1 & 35.4 & 27.2 & 30.6 & 25.0 * \\
\hline Less Than High School & 41.9 & 44.3 & 41.3 & 45.1 & 44.1 & 38.5 & 35.7 & 33.1 \\
\hline High School Graduate & 18.1 & 18.0 & 16.9 & 18.8 & 23.0 & 14.1 & 19.7 & 13.1 * \\
\hline College Graduate & 8.6 & 0.0 & 0.0 & 0.0 & 0.0 & 0.0 & 2.8 & 0.0 \\
\hline Number of observations & 2080 & 2040 & 1994 & 1947 & 1234 & 1195 & 1719 & 1638 \\
\hline
\end{tabular}

Source: Authors' estimates from the 1992 - 2006 waves of the Health and Retirement Study.

Notes: Financial hardship is defined as having own and spousal income below 100 percent of the federal poverty level. Estimates for all

age groups use poverty thresholds for households younger that 65 . The sample is restricted to respondents who were interviewed in 1992 and completed each interview through age 62 or until they died. The 1999 and 2001 samples exclude respondents age 62 . Asterisks indicate that estimates differ significantly from 1999 estimates $\left({ }^{*} .05<p<.1,{ }^{* \star} p<.05\right)$. 
Table 9. Share of Adults Born Between 1937 and 1939 Falling into Financial Hardship Before Age 62, Among Those Not in Economic Hardship in 1992

\section{All Adults}

14.5

$16.4^{* *}$

12.6

$32.7^{* *}$

$12.0 * \star$

4.5

$28.4^{* *}$

35.1 **

11.5

26.8 **

11.7

51.6 **

45.2 **

38.1 **

11.0

13.9

17.4

10.4 *

22.4

27.2 **

16.7 **

$11.6^{* *}$

19.0 **

5.0

2524
Adults Working Full Time in 1992

\section{Laid Off Before 62}

Yes

10.7

11.4

10.1

25.6 ** 8.6 **

5.0

19.8 ** $27.4^{* *}$ 8.4

21.0 ** 7.7

$38.1^{* *}$ $40.7^{\text {** }}$ $30.4^{* *}$ 8.9

9.6 ** 15.2

9.5 ** 13.8

$14.7^{* *}$

$11.6^{* *}$ 19.0 ** 5.0 1666

Source: Authors' estimates from the 1992 - 2006 waves of the Health and Retirement Study. Note: Financial hardship is defined as having income below the federal poverty level. The sample is restricted to adults who are not in economic hardship in 1991. Asterisks indicate that estimates differ significantly from those reported in the last row of each category $\left({ }^{*} .05<p<.1\right.$, $\left.{ }^{* *} p<.05\right)$. 
Table 10. Marginal Impact of Personal Characteristics on the Probability of Falling Into Economic Hardship, Ages 51-73

\begin{tabular}{|c|c|c|c|c|c|c|}
\hline & \multicolumn{2}{|c|}{ Baseline Specification } & \multicolumn{2}{|c|}{$\begin{array}{l}\text { Including Education and } \\
\text { Health Interactions }\end{array}$} & \multicolumn{2}{|c|}{$\begin{array}{l}\text { Including Age and } \\
\text { Health Interactions }\end{array}$} \\
\hline & $\begin{array}{r}\text { Marginal } \\
\text { Effect } \\
\end{array}$ & $\begin{array}{r}\text { Standard } \\
\text { Error } \\
\end{array}$ & $\begin{array}{r}\text { Marginal } \\
\text { Effect } \\
\end{array}$ & $\begin{array}{r}\text { Standard } \\
\text { Error } \\
\end{array}$ & $\begin{array}{r}\text { Marginal } \\
\text { Effect }\end{array}$ & $\begin{array}{r}\text { Standard } \\
\text { Error } \\
\end{array}$ \\
\hline \multicolumn{7}{|l|}{ Age, Wave $t$} \\
\hline [Ref: 51-54] & $\ldots$ & $\ldots$ & $\ldots$ & $\ldots$ & $\ldots$ & $\ldots$ \\
\hline $55-56$ & 0.0084 ** & 0.0040 & 0.0084 ** & 0.0040 & 0.0050 & 0.0043 \\
\hline $57-58$ & $0.0129 \star \star \star$ & 0.0040 & $0.0129 * * *$ & 0.0041 & 0.0058 & 0.0041 \\
\hline $59-61$ & $0.0121 * \star \star$ & 0.0036 & 0.0122 *** & 0.0036 & 0.0093 *** & 0.0038 \\
\hline $62-64$ & -0.0005 & 0.0034 & -0.0005 & 0.0034 & -0.0001 & 0.0038 \\
\hline $65-66$ & -0.0066 * & 0.0034 & -0.0066 * & 0.0035 & -0.0045 & 0.0041 \\
\hline $67-68$ & $-0.0152 * \star *$ & 0.0030 & $-0.0153 * \star \star$ & 0.0030 & $-0.0147 * * \star$ & 0.0031 \\
\hline $69+$ & -0.0076 ** & 0.0034 & $-0.0075 * *$ & 0.0034 & $-0.0066 *$ & 0.0036 \\
\hline Male & $-0.0046 * * *$ & 0.0016 & $-0.0046 * \star \star *$ & 0.0016 & $-0.0045 * \star *$ & 0.0016 \\
\hline \multicolumn{7}{|l|}{ Race and Ethnicity } \\
\hline African American & $0.0403 * * \star$ & 0.0045 & $0.0405 * * *$ & 0.0045 & $0.0404 * \star \star$ & 0.0045 \\
\hline Hispanic & $0.0445 * \star \star$ & 0.0064 & $0.0447 * \star \star$ & 0.0065 & $0.0444^{\star \star \star}$ & 0.0065 \\
\hline [Ref: White or other] & $\cdots$ & $\cdots$ & $\cdots$ & $\cdots$ & $\cdots$ & $\cdots$ \\
\hline \multicolumn{7}{|l|}{ Education } \\
\hline $\begin{array}{l}\text { Not high school graduate } \\
\text { [Ref: high school graduate] }\end{array}$ & $\begin{array}{c}0.0306 * \star * \\
\ldots\end{array}$ & $\begin{array}{r}0.0026 \\
\ldots\end{array}$ & $\begin{array}{c}0.0272 * * * \\
\ldots\end{array}$ & 0.0031 & $0.0272 * \star \star$ & 0.0031 \\
\hline College graduate & $-0.0170 * \star \star$ & 0.0021 & $-0.0172 * \star \star$ & 0.0021 & $-0.0173 * \star *$ & 0.0021 \\
\hline \multicolumn{7}{|l|}{ Health Limitations } \\
\hline Limitation at wave $t$ & $0.0431 * \star \star$ & 0.0028 & $0.0392 * * *$ & 0.0034 & $0.0309 * \star \star$ & 0.0053 \\
\hline Limitation at wave $t+1$, but not $t$ & $0.0314 * \star \star$ & 0.0041 & $0.0316 * * \star$ & 0.0041 & $0.0314^{* * *}$ & 0.0041 \\
\hline Limitation at wave $t$, but not $t+1$ & $-0.0131 * \star \star$ & 0.0023 & $-0.0130 * \star \star$ & 0.0023 & $-0.0130 * \star \star$ & 0.0023 \\
\hline \multicolumn{7}{|l|}{ Current Health Limitation and Not } \\
\hline High School Graduate & $\ldots$ & $\ldots$ & 0.0068 * & 0.0038 & $0.0071 *$ & 0.0038 \\
\hline \multicolumn{7}{|c|}{ Age and Health Limitation (wave $t$ ) Interactions } \\
\hline 55-56 * Health Limitation & $\ldots$ & $\ldots$ & $\ldots$ & $\ldots$ & 0.0118 & 0.0079 \\
\hline $57-58$ * Health Limitation & $\ldots$ & $\ldots$ & $\ldots$ & $\ldots$ & $0.0242 * \star \star$ & 0.0086 \\
\hline 59-61 * Health Limitation & $\ldots$ & $\ldots$ & $\ldots$ & $\ldots$ & $0.0099 *$ & 0.0058 \\
\hline $62-64$ * Health Limitation & $\ldots$ & $\ldots$ & $\ldots$ & $\ldots$ & 0.0007 & 0.0050 \\
\hline 65-66 * Health Limitation & $\ldots$ & $\ldots$ & $\ldots$ & $\ldots$ & -0.0042 & 0.0057 \\
\hline \multicolumn{7}{|l|}{ Marital Status } \\
\hline Married at wave $t$ & $-0.0668 * \star \star$ & 0.0041 & $-0.0670 * \star \star$ & 0.0042 & -0.0673 *** & 0.0042 \\
\hline Married at wave $t+1$, not at $t$ & $-0.0226 * \star \star$ & 0.0030 & $-0.0226 * \star \star$ & 0.0030 & $-0.0227 * \star \star$ & 0.0030 \\
\hline Married at wave $t$, divorced at $t+1$ & 0.1269 ** & 0.0191 & $0.1270 * \star \star$ & 0.0191 & 0.1260 *** & 0.0190 \\
\hline Married at wave $t$, widowed at $t+1$ & $0.1153 * \star \star$ & 0.0130 & $0.1157 * * \star$ & 0.0130 & $0.1156 * \star \star$ & 0.0130 \\
\hline \multicolumn{7}{|l|}{ Spouse Characteristics } \\
\hline African American & -0.0035 & 0.0033 & -0.0034 & 0.0033 & -0.0033 & 0.0034 \\
\hline Hispanic & $0.0102 * \star$ & 0.0051 & 0.0106 ** & 0.0051 & $0.0109 * *$ & 0.0052 \\
\hline Not high school graduate & 0.0214 *** & 0.0030 & $0.0215 * * *$ & 0.0030 & $0.0216 * \star \star$ & 0.0030 \\
\hline College graduate & $-0.0088^{* \star *}$ & 0.0030 & 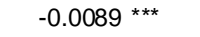 & 0.0030 & -0.0088 *** & 0.0030 \\
\hline Health limitation at wave $t$ & 0.0126 *** & 0.0026 & $0.0126 * * *$ & 0.0026 & 0.0127 *** & 0.0026 \\
\hline National Poverty Rate, Wave $t+1$ & 0.0007 & 0.0008 & 0.0007 & 0.0008 & 0.0007 & 0.0008 \\
\hline \multicolumn{7}{|l|}{ Mean Likelihood of Falling into } \\
\hline Financial Hardship & \multicolumn{2}{|l|}{0.055} & \multicolumn{2}{|l|}{0.055} & \multicolumn{2}{|l|}{0.055} \\
\hline \multicolumn{7}{|l|}{ Mean Predicted Likelihood of } \\
\hline $\begin{array}{l}\text { Falling into Financial Hardship } \\
\mathbf{N}\end{array}$ & \multicolumn{2}{|l|}{0.032} & \multicolumn{2}{|l|}{0.032} & 0.032 & 46,060 \\
\hline Pseudo $\mathrm{R}^{2}$ & 0.160 & & 0.160 & & 0.161 & \\
\hline
\end{tabular}

Source: Authors' estimates from 1992 - 2006 waves of the Health and Retirement Study (HRS).

Notes: The table reports results from a probit model of the probabilty of having own and spousal income below the poverty level at wave $t+1$, conditional on having income above the poverty level at wave $t$. Estimates are based on a sample of person-year observations for adults born between 1931 to 1941 whose income is measured every other year from 1993 to 2005 . Asterisks indicate statistically significant effects $(* .05<p<.10 ; \quad * \star .01<p<.05 ; \quad * \star *<.01)$. 
Table 11. Marginal Impact of Personal Characteristics on the Probability of Falling Into Economic Hardship, Men Ages 51-73

\begin{tabular}{|c|c|c|c|c|c|c|}
\hline & \multicolumn{2}{|c|}{ Baseline Specification } & \multicolumn{2}{|c|}{$\begin{array}{l}\text { Including Education and } \\
\text { Health Interactions }\end{array}$} & \multicolumn{2}{|c|}{$\begin{array}{l}\text { Including Age and } \\
\text { Health Interactions }\end{array}$} \\
\hline & $\begin{array}{r}\text { Marginal } \\
\text { Effect }\end{array}$ & $\begin{array}{r}\text { Standard } \\
\text { Error } \\
\end{array}$ & $\begin{array}{r}\text { Marginal } \\
\text { Effect }\end{array}$ & $\begin{array}{r}\text { Standard } \\
\text { Error } \\
\end{array}$ & $\begin{array}{r}\text { Marginal } \\
\text { Effect }\end{array}$ & $\begin{array}{r}\text { Standard } \\
\text { Error } \\
\end{array}$ \\
\hline \multicolumn{7}{|l|}{ Age, Wave $t$} \\
\hline $55-56$ & 0.0079 & 0.0055 & 0.0079 & 0.0055 & 0.0020 & 0.0057 \\
\hline $57-58$ & 0.0114 ** & 0.0055 & $0.0117 * \star$ & 0.0056 & 0.0054 & 0.0057 \\
\hline $59-61$ & $0.0162 * \star *$ & 0.0053 & $0.0164 * \star \star$ & 0.0053 & $0.0120 * *$ & 0.0055 \\
\hline $62-64$ & 0.0025 & 0.0048 & 0.0024 & 0.0048 & 0.0035 & 0.0054 \\
\hline $65-66$ & -0.0069 & 0.0045 & -0.0070 & 0.0045 & -0.0031 & 0.0057 \\
\hline $67-68$ & $-0.0105 * \star \star$ & 0.0043 & $-0.0107 * \star \star *$ & 0.0044 & -0.0101 ** & 0.0045 \\
\hline $69+$ & -0.0048 & 0.0049 & -0.0048 & 0.0049 & -0.0038 & 0.0051 \\
\hline \multicolumn{7}{|l|}{ Race and Ethnicity } \\
\hline African American & $0.0295 * \star \star$ & 0.0072 & $0.0300 * \star \star$ & 0.0072 & 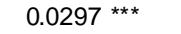 & 0.0072 \\
\hline Hispanic & $0.0439 * \star \star$ & 0.0097 & $0.0450 * * *$ & 0.0099 & $0.0444 * \star *$ & 0.0099 \\
\hline [Ref: White or other] & $\cdots$ & $\cdots$ & $\cdots$ & $\ldots$ & $\ldots$ & $\ldots$ \\
\hline \multicolumn{7}{|l|}{ Education } \\
\hline $\begin{array}{l}\text { Not high school graduate } \\
\text { [Ref: high school graduate] }\end{array}$ & $0.0233 * *$ & 0.0034 & $0.0157 * \star \star$ & 0.0038 & $0.0155 * \star *$ & 0.0038 \\
\hline College graduate & $-0.0096 * \star \star * \pi$ & 0.0029 & $-0.0101 * * \star$ & 0.0029 & $-0.0102 * \star *$ & 0.0029 \\
\hline \multicolumn{7}{|l|}{ Health Limitations } \\
\hline Limitation at wave $t$ & 0.0396 *** & 0.0040 & $0.0304 * \star \star *$ & 0.0045 & 0.0214 ** & 0.0070 \\
\hline Limitation at wave $t+1$, but not $t$ & 0.0314 *** & 0.0041 & $0.0316 * \star \star$ & 0.0041 & $0.0314 * \star *$ & 0.0041 \\
\hline Limitation at wave $t$, but not $t+1$ & $-0.0131 * \star \star *$ & 0.0023 & $-0.0130 * \star *$ & 0.0023 & $-0.0130 * \star \star$ & 0.0023 \\
\hline \multicolumn{7}{|l|}{ Current Health Limitation and Not } \\
\hline High School Graduate & $\ldots$ & $\ldots$ & $0.0176 * * \star$ & 0.0065 & 0.0191 & 0.0067 \\
\hline \multicolumn{7}{|c|}{ Age and Health Limitation (wave $t$ ) Interactions } \\
\hline $55-56$ * Health Limitation & $\ldots$ & $\ldots$ & $\ldots$ & $\ldots$ & 0.0221 & 0.0135 \\
\hline $57-58$ * Health Limitation & $\ldots$ & $\ldots$ & $\ldots$ & $\ldots$ & 0.0218 * & 0.0119 \\
\hline 59-61 * Health Limitation & $\ldots$ & $\ldots$ & $\ldots$ & $\ldots$ & 0.0132 & 0.0085 \\
\hline 62-64 * Health Limitation & $\ldots$ & $\ldots$ & $\ldots$ & $\ldots$ & -0.0012 & 0.0064 \\
\hline 65-66 * Health Limitation & $\cdots$ & $\ldots$ & $\cdots$ & $\cdots$ & -0.0088 & 0.0065 \\
\hline \multicolumn{7}{|l|}{ Marital Status } \\
\hline Married at wave $t$ & $-0.0511 * \star \star$ & 0.0062 & $-0.0515 * \star \star$ & 0.0062 & $-0.0519 * \star \star$ & 0.0062 \\
\hline Married at wave $t+1$, not at $t$ & $-0.0238 * \star *$ & 0.0023 & $-0.0240 * \star \star *$ & 0.0023 & $-0.0241 * \star \star *$ & 0.0023 \\
\hline Married at wave $t$, divorced at $t+1$ & 0.0616 *** & 0.0190 & 0.0611 *** & 0.0189 & 0.0594 *** & 0.0188 \\
\hline Married at wave $t$, widowed at $t+1$ & 0.0329 * & 0.0150 & 0.0323 ** & 0.0150 & 0.0322 * & 0.0150 \\
\hline \multicolumn{7}{|l|}{ Spouse Characteristics } \\
\hline African American & -0.0022 & 0.0049 & -0.0019 & 0.0049 & -0.0019 & 0.0050 \\
\hline Hispanic & 0.0044 & 0.0060 & 0.0051 & 0.0061 & 0.0053 & 0.0062 \\
\hline Not high school graduate & $0.0227 \star \star \star *$ & 0.0041 & $0.0226 * \star \star$ & 0.0041 & $0.0228 * \star \star$ & 0.0041 \\
\hline College graduate & $-0.0098 * \star \star$ & 0.0036 & $-0.0102 * \star \star \star x$ & 0.0036 & $-0.0101 * \star \star$ & 0.0036 \\
\hline Health limitation at wave $t$ & 0.0121 ** & 0.0033 & $0.0121 * \star \star$ & 0.0033 & 0.0122 *** & 0.0033 \\
\hline National Poverty Rate, Wave $t+1$ & -0.0001 & 0.0011 & -0.0001 & 0.0011 & -0.0001 & 0.0011 \\
\hline \multicolumn{7}{|l|}{ Mean Likelihood of Falling into } \\
\hline Financial Hardship & 0.043 & & 0.043 & & 0.043 & \\
\hline \multicolumn{7}{|l|}{ Mean Predicted Likelihood of } \\
\hline Falling into Financial Hardship & 0.027 & & 0.027 & & 0.027 & \\
\hline $\mathbf{N}$ & 21,652 & & 21,652 & & 21,652 & \\
\hline Pseudo $\mathbf{R}^{2}$ & 0.142 & & 0.143 & & 0.146 & \\
\hline
\end{tabular}

Source: Authors' estimates from 1992 - 2006 waves of the Health and Retirement Study (HRS).

Notes: The table reports results from a probit model of the probabilty of having own and spousal income below the poverty level at wave $t+1$, conditional on having income above the poverty level at wave $t$. Estimates are based on a sample of person-year observations for men born between 1931 to 1941 whose income is measured every other year from 1993 to 2005. Asterisks indicate statistically significant effects $\left({ }^{*} .05<p<.10 ; \quad * \star .01<p<.05 ; \quad * \star *<.01\right)$. 
Table 12. Marginal Impact of Personal Characteristics on the Probability of Falling Into Economic Hardship, Women Ages 51-73

\begin{tabular}{|c|c|c|c|c|c|c|}
\hline & \multicolumn{2}{|c|}{ Baseline Specification } & \multicolumn{2}{|c|}{$\begin{array}{l}\text { Including Education and } \\
\text { Health Interactions }\end{array}$} & \multicolumn{2}{|c|}{$\begin{array}{l}\text { Including Age and } \\
\text { Health Interactions }\end{array}$} \\
\hline & $\begin{array}{r}\text { Marginal } \\
\text { Effect }\end{array}$ & $\begin{array}{r}\text { Standard } \\
\text { Error }\end{array}$ & $\begin{array}{r}\text { Marginal } \\
\text { Effect }\end{array}$ & $\begin{array}{r}\text { Standard } \\
\text { Error } \\
\end{array}$ & $\begin{array}{r}\text { Marginal } \\
\text { Effect }\end{array}$ & $\begin{array}{r}\text { Standard } \\
\text { Error } \\
\end{array}$ \\
\hline \multicolumn{7}{|l|}{ Age, Wave $t$} \\
\hline $55-56$ & 0.0089 & 0.0057 & 0.0089 & 0.0057 & 0.0073 & 0.0063 \\
\hline $57-58$ & $0.0146 * * *$ & 0.0059 & $0.0146 * \star *$ & 0.0059 & 0.0065 & 0.0061 \\
\hline $59-61$ & 0.0088 * & 0.0050 & 0.0088 * & 0.0050 & 0.0071 & 0.0054 \\
\hline $62-64$ & -0.0033 & 0.0048 & -0.0033 & 0.0048 & -0.0035 & 0.0053 \\
\hline $65-66$ & -0.0065 & 0.0052 & -0.0065 & 0.0052 & -0.0056 & 0.0060 \\
\hline $67-68$ & $-0.0194 * \star \star$ & 0.0042 & $-0.0194 * \star * *$ & 0.0042 & -0.0188 *** & 0.0043 \\
\hline $69+$ & -0.0101 ** & 0.0049 & $-0.0101 * \star$ & 0.0049 & $-0.0092 *$ & 0.0050 \\
\hline \multicolumn{7}{|l|}{ Race and Ethnicity } \\
\hline African American & $0.0474 * \star *$ & 0.0059 & $0.0474 * \star \star *$ & 0.0059 & $0.0475 * \star \star$ & 0.0059 \\
\hline Hispanic & $0.0460 * * *$ & 0.0088 & $0.0460 * \star \star$ & 0.0088 & $0.0458 * \star *$ & 0.0088 \\
\hline [Ref: White or other] & $\cdots$ & $\ldots$ & $\ldots$ & $\ldots$ & & \\
\hline \multicolumn{7}{|l|}{ Education } \\
\hline Not high school graduate & $0.0375 * \star$ & 0.0039 & 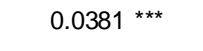 & 0.0047 & 0.0382 ** & 0.0047 \\
\hline $\begin{array}{l}\text { [Ref: high school graduate] } \\
\text { College graduate }\end{array}$ & $\begin{array}{l}\ldots \\
-0.0249 * *\end{array}$ & $\begin{array}{l}\ldots \\
0.0028\end{array}$ & $\begin{array}{l}\ldots \\
-0.0249 * *\end{array}$ & 0.0028 & $\begin{array}{l}\ldots \\
-0.0249 * * *\end{array}$ & 0.0028 \\
\hline \multicolumn{7}{|l|}{ Health Limitations } \\
\hline Limitation at wave $t$ & 0.0474 *** & 0.0041 & $0.0480 * \star \star$ & 0.0050 & 0.0401 *** & 0.0078 \\
\hline Limitation at wave $t+1$, but not $t$ & 0.0418 *** & 0.0063 & $0.0417 * \star \star$ & 0.0063 & $0.0415 * \star *$ & 0.0063 \\
\hline Limitation at wave $t$, but not $t+1$ & $-0.0154 * \star \star$ & 0.0035 & $-0.0154 * \star \star$ & 0.0035 & -0.0154 *** & 0.0035 \\
\hline \multicolumn{7}{|l|}{ Current Health Limitation and Not } \\
\hline High School Graduate & & & -0.0011 & 0.0048 & -0.0012 & 0.0048 \\
\hline \multicolumn{7}{|c|}{ Age and Health Limitation (wave $t$ ) Interactions } \\
\hline 55-56 * Health Limitation & & & & & 0.0058 & 0.0102 \\
\hline 57-58 * Health Limitation & & & & & 0.0271 ** & 0.0124 \\
\hline 59-61 * Health Limitation & & & & & 0.0065 & 0.0080 \\
\hline 62-64 * Health Limitation & & & & & 0.0026 & 0.0077 \\
\hline 65-66 * Health Limitation & & & & & -0.0008 & 0.0090 \\
\hline \multicolumn{7}{|l|}{ Marital Status } \\
\hline Married at wave $t$ & $-0.0795 * \star *$ & 0.0056 & $-0.0795 * \star *$ & 0.0056 & $-0.0797 * \star *$ & 0.0056 \\
\hline Married at wave $t+1$, not at $t$ & $-0.0160 * \star$ & 0.0072 & $-0.0160 * *$ & 0.0072 & -0.0162 ** & 0.0072 \\
\hline Married at wave $t$, divorced at $t+1$ & 0.2152 *** & 0.0346 & $0.2151 * \star *$ & 0.0346 & 0.2141 *** & 0.0345 \\
\hline Married at wave $t$, widowed at $t+1$ & 0.1684 *** & 0.0182 & $0.1683 * \star \star$ & 0.0182 & 0.1683 *** & 0.0182 \\
\hline \multicolumn{7}{|l|}{ Spouse Characteristics } \\
\hline African American & -0.0004 & 0.0053 & -0.0004 & 0.0053 & -0.0003 & 0.0053 \\
\hline Hispanic & 0.0162 ** & 0.0083 & 0.0161 * & 0.0083 & 0.0164 ** & 0.0083 \\
\hline Not high school graduate & 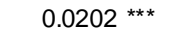 & 0.0046 & $0.0202 * * *$ & 0.0046 & $0.0201 * \star *$ & 0.0046 \\
\hline College graduate & -0.0068 & 0.0048 & -0.0068 & 0.0048 & -0.0068 & 0.0048 \\
\hline Health limitation at wave $t$ & 0.0131 ** & 0.0040 & $0.0131 * \star *$ & 0.0040 & 0.0132 *** & 0.0040 \\
\hline National Poverty Rate, Wave $t+1$ & -0.0001 & 0.0013 & 0.0015 & 0.0013 & 0.0015 & 0.0013 \\
\hline \multicolumn{7}{|l|}{ Mean Likelihood of Falling into } \\
\hline Financial Hardship & 0.065 & & 0.065 & & 0.065 & \\
\hline \multicolumn{7}{|l|}{ Mean Predicted Likelihood of } \\
\hline Falling into Financial Hardship & 0.038 & & 0.038 & & 0.038 & \\
\hline $\mathbf{N}$ & 24,408 & & 24,408 & & 24,408 & \\
\hline Pseudo $\mathrm{R}^{2}$ & 0.171 & & 0.171 & & 0.172 & \\
\hline
\end{tabular}

Source: Authors' estimates from 1992 - 2006 waves of the Health and Retirement Study (HRS).

Notes: The table reports results from a probit model of the probabilty of having own and spousal income below the poverty level at wave $t+1$, conditional on having income above the poverty level at wave $t$. Estimates are based on a sample of person-year observations for women born between 1931 to 1941 whose income is measured every other year from 1993 to 2005. Asterisks indicate statistically significant effects $\left({ }^{\star} .05<p<.10 ; \quad * \star .01<p<.05 ; \quad * \star *<<.01\right)$. 


\section{RECENT WORKING PAPERS FROM THE}

\section{CENTER FOR RETIREMENT RESEARCH AT BOSTON COLLEGE}

Rising Tides and Retirement: The Aggregate and Distributional Effects of Differential Wage Growth on Social Security

Melissa M. Favreault, March 2009

Accounting for the Heterogeneity in Retirement Wealth

Fang Yang, January 2009

Labor Supply Elasticity and Social Security Reform

Selahattin Imrohorolu and Sagiri Kitao, January 2009

Evaluating Micro-Survey Estimates of Wealth and Saving

Barry P. Bosworth and Rosanna Smart, January 2009

Portfolio Choice in Retirement: Health Risk and the Demand for Annuities, Housing, and Risky Assets

Motohiro Yogo, January 2009

The Disappearing Defined Benefit Pension and its Potential Impact on the Retirement Incomes of Boomers

Barbara A. Butrica, Howard M. Iams, Karen E. Smith, and Eric J. Toder, January 2009

Retirement and Social Security: A Time Series Approach

Brendan Cushing-Daniels and C. Eugene Steuerle, January 2009

Economic Restructuring and Retirement in Urban China

John Giles, January 2009

Sources of Support for Pension Reform: A Cross-National Perspective

Michelle Dion and Andrew Roberts, January 2009

The Long-Term Effect of the Divorce Revolution: Health, Wealth, and Labor Supply

Kristin Mammen, December 2008

The Response of Household Saving to the Large Shock of German Reunification Nicola Fuchs-Schündeln, November 2008

All working papers are available on the Center for Retirement Research website (http://www.bc.edu/crr) and can be requested by e-mail (crr@bc.edu) or phone (617-552-1762). 